\title{
The emergence of a new chlorophytan system, and Dr. Kornmann's contribution thereto*
}

\author{
C. van den Hoek, W. T. Stam \& J. L. Olsen \\ Department of Marine Biology, Biological Centre of the University of Groningen; \\ PO Box 14, 9750 AA Haren (Gn), The Netherlands
}

\begin{abstract}
In traditional chlorophytan systems the organizational level was the primary character for the distinction of main groups (classes and orders). For instance, in Fott (1971), the flagellate level corresponds with the Volvocales, the coccoid level with the Chlorococcales, the filamentous level with the Ulotrichales, the siphonocladous level with the Siphonocladales, and the siphonous level with the Bryopsidales. The new system presented here is an elaboration and emendation of recently proposed taxonomies and their underlying phylogenetic hypotheses, and it is mainly based on ultrastructural features which have become available over the last 15 years. The following criteria are used for the distinction of classes and orders: (1) architecture of the flagellate cell (flagellate cells are considered as the depositories of primitive characters); (2) type of mitosis-cytokinesis; (3) place of meiosis in the life history and, consequently, the sexual life history type; (4) organizational level and thallus architecture; (5) habitat type (marine versus feshwater and terrestrial); (6) chloroplast type. The following classes are presented: Prasinophyceae, Chlamydophyceae, Ulvophyceae (orders Codiolales, Ulvales, Cladophorales, Bryopsidales, Dasycladales), Pleurastrophyceae (?), Chlorophyceae s.s. (orders Cylindrocapsales, Oedogoniales, Chaetophorales), Zygnematophyceae, Trentepohliophyceae, Charophyceae (orders Klebsormidiales, Coleochaetales, Charales). The new system no longer reflects the traditional hypothesis of a stepwise evolutionary progression of organizational levels in which the flagellate level represents the most primitive lineage, the coccoid and sarcinoid levels lineages of intermediate derivation, and the filamentous, siphonocladous and siphonous levels the most derived lineages. Instead, it is now hypothesized that these levels have arisen over and over again in different chlorophytan lineages which are primarily characterized by their type of flagellate cell. The flagellate green algal classes Prasinophyceae (with organic body scales) and Chlamydophyceae probably represent bundles of highly conservative lineages that diverged very long ago. Consequently, extant genera and species in these classes can be expected to have emerged long ago. Fossil evidence points to a minimum age of $600 \mathrm{Ma}$ of certain extant Prasinophycean genera, and molecular evidence to a minimum age of 400-500 Ma of a few Chlamydomonas species. On the contrary, the most derived "green algal" lineage, the Angiosperms, can be expected to consist of, on average, much younger genera and species. Fossil evidence points to a minimum age of genera of 5-60 Ma. Lineages of intermediate evolutionary derivation (Ulvophyceae, Chlorophyceae, Charophyceae) can be expected to encompass genera and species of intermediate age. Fossil and (limited) molecular evidence point to a minimum age of 230-70 Ma of extant genera in Bryopsidales, Dasycladales and Cladophorales (Ulvophyceae) and of 250-80 Ma of extant genera in Charales (Charophyceae).
\end{abstract}

* Dedicated to Dr. h. c. P. Kornmann, on the occasion of his 80 th birthday. 


\section{TRADITIONAL CHLOROPHYTAN SYSTEMS}

In traditional chlorophytan systems (e.g. Fritsch, 1948; Fott, 1971; van den Hoek \& Jahns, 1978; Bold \& Wynne, 1985; Bold et al., 1987) the organizational level was the primary character used for the distinction of the main groups (orders, classes) within the division Chlorophyta.

Table 1. Subdivision of Chlorophyta according to Fott (1971)

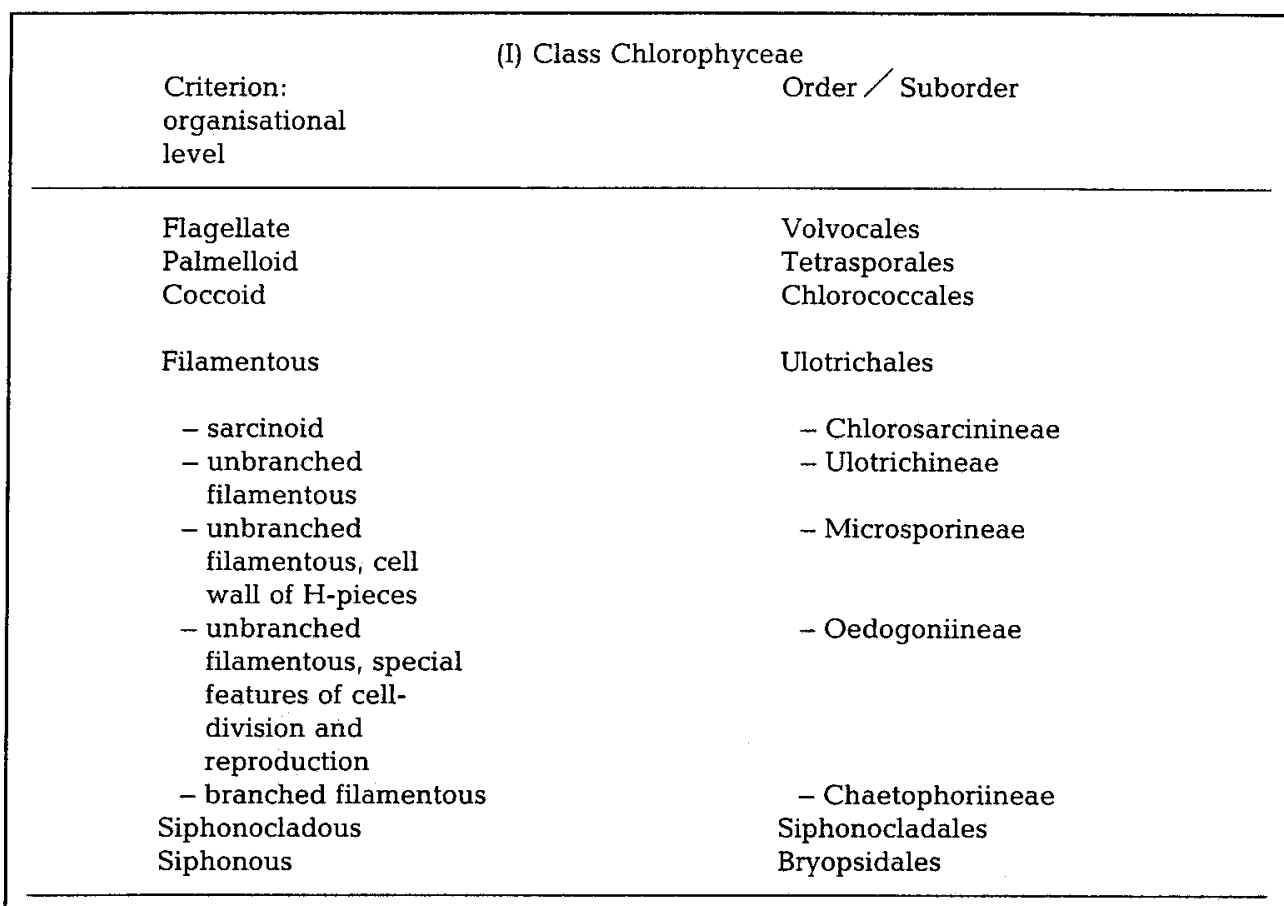

(II) Class Conjugatophyceae

Essentially with coccoid organisational level, special features of reproduction (conjugation).

(III) Class Charophyceae

Special vegetative and reproductive architecture

As an example, Fott's chlorophytan system of 1971 is presented in Table 1. This system reflects the phylogenetic hypothesis that flagellate unicellular chlorophytes are primitive and have evolved, through coccoid and sarcinoid chlorophytes, into filamentous and siphonous chlorophytes. This hypothesis is illustrated by Figure 1. It reflects ideas developed already by Blackman (1900) and Pascher (1914). According to this hypothesis, the Bryophytes and Tracheophytes are derived from branched filamentous chlorophytes. 


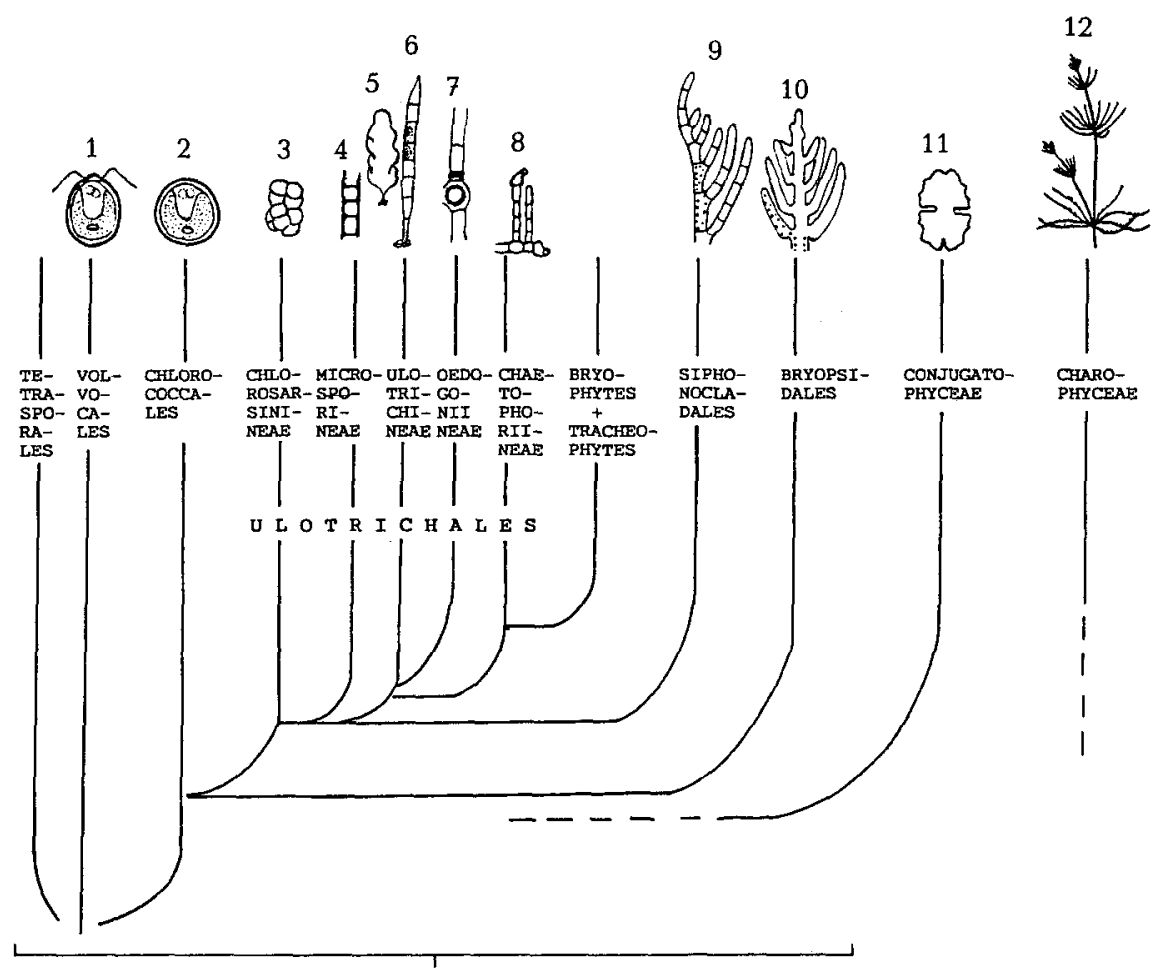

CH L ORO P H Y CEAE

Fig. 1. Phylogeny and subdivision of Chlorophyta according to Fott (1971). 1 Flagellate organizational level (Chlamydomonas). 2 Coccoid organizational level (Chlorococcum). 3 Sarcinoid (= package-like) organizational level (Chlorosarcinopsis). 4 Filamentous organizational level (Microspora). 5 Thallose organizational level, derived from the filamentous level (Ulva). 6 Filamentous organizational level (Uronema). 7 Filamentous organizational level (Oedogonium). 8 Branched filamentous organizational level (Trentepohlia). 9 Siphonocladous organizational level (Cladophora). 10 Siphonous organizational level (Bryopsis). 11 Coccoid organizational level, special features (Euastrum). 12 Chara-like architecture (Chara)

Fott points to the terrestrial chlorophytes Fritschiella and Trentepohlia as possible representatives of ancestral groups of the higher land plants.

When in 1971 Fott presented his overview of the then, and perhaps even now, predominant hypothesis about chlorophytan phylogeny, Dr. Kornmann was already sowing the seeds of revolution against its basic assumption. Dr. Kornmann had realized that a group of morphologically very divergent green algae should be united into one order or even class (Kornmann, 1963, 1973), because they share a very characteristic type of life history including a unicellular Codiolum-like stage containing the zygote nucleus. In 1973 he proposed to range these chlorophytes in the class Codiolophyceae. This class included algae of the coccoid (Kornmann \& Sahling, 1983), unbranched filamentous, branched filamentous, siphonocladous and thallose organisational levels.

The concept of the Codiolophyceae would of course disrupt the basis of the traditional system and phylogeny, namely the assumption that each organizational level should represent one principal evolutionary lineage within the Chlorophyta. 
In the meantime a number of other researchers (e.g. Pickett-Heaps, Stewart \& Mattox, Moestrup, Melkonian, Floyd, O'Kelly, Lokhorst, Sluiman, Pienaar, Norris, Hori, Triemer, Roberts) gradually accumulated an enormous amount of fascinating mainly ultrastructural information which did not support the traditional hypothesis that the increasingly derived organizational levels represent the main evolutionary lineages within the Chlorophyta.

In the course of the past 15 years various reconstructions of the chlorophytan system and phylogeny have been proposed on the basis of all these new data (Mattox \& Stewart, 1984; Melkonian, 1982; O'Kelly \& Floyd, 1984; Stewart \& Mattox, 1978; Sluiman, 1985b; Sluiman et al., 1980a). The system which we will present here is a further elaboration and emendation of these proposals, whose essence is, in their most recent form, a subdivision of the Chlorophyta into four main evolutionary lineages (classes): the Prasinophyceae, the Chlorophyceae, the Ulvophyceae, and the Charophyceae.

\section{A NEW CHLOROPHYTAN SYSTEM}

First of all, we propose a new subdivision of the Chlorophyta in classes and orders (Table 2). Secondly, we will shortly treat the main criteria used for this subdivision (Table 2 and below). Thirdly, we will discuss several implications of the new system and its underlying phylogenetic hypotheses; implications which are often overlooked.

\section{Criteria for the distinction of chlorophytan classes and orders}

See Table 2 for the main criteria.

\section{Architecture of the flagellate cell}

The evolutionary importance ascribed to the architecture of the flagellate cell is based on the concept that this architecture tends to be conservative because flagellate cells, with their typical eukaryotan flagella having the " $9+2$ " axoneme, occur in widely different eukaryotan organisms (e.g. most algal groups, certain fungi, ferns, animals). The implication of this concept is that unicellular flagellate organisms tend to be evolutionarily more conservative than non-flagellate multicellular or multinucleate organisms.

Within the chlorophytes, at least five or even six different types of flagellate cells have now been recognized.

(1) Free living flagellate cells whose bodies and flagella are covered by several layers of more or less elaborate organic scales which are produced in Golgi-bodies (Fig. 2).

This type is deemed characteristic of the class Prasinophyceae. The form of the cell and the construction of the flagellar apparatus, i.e. the root system anchoring the flagella in the cell, are highly variable (Fig. 18). However, the possession of prominent transversely striated rhizoplasts is considered characteristic of this type (Fig. 3). (A selection of references: Ettl, 1983; Hori et al, 1985, 1986; Inouye et al., 1983, 1985; Melkonian, 1981a; Moestrup, 1982; Moestrup \& Ettl, 1979; Moestrup \& Walne, 1979; Norris, 1980, 1982; Norris \& Pienaar, 1978; Parke et al., 1978; Pennick, 1984; Pienaar \& Aken, 1985).

(2) Flagellate cells of the cruciate type with a l o'clock/7 o'clock configuration of the flagellar apparatus (Fig. 4). 


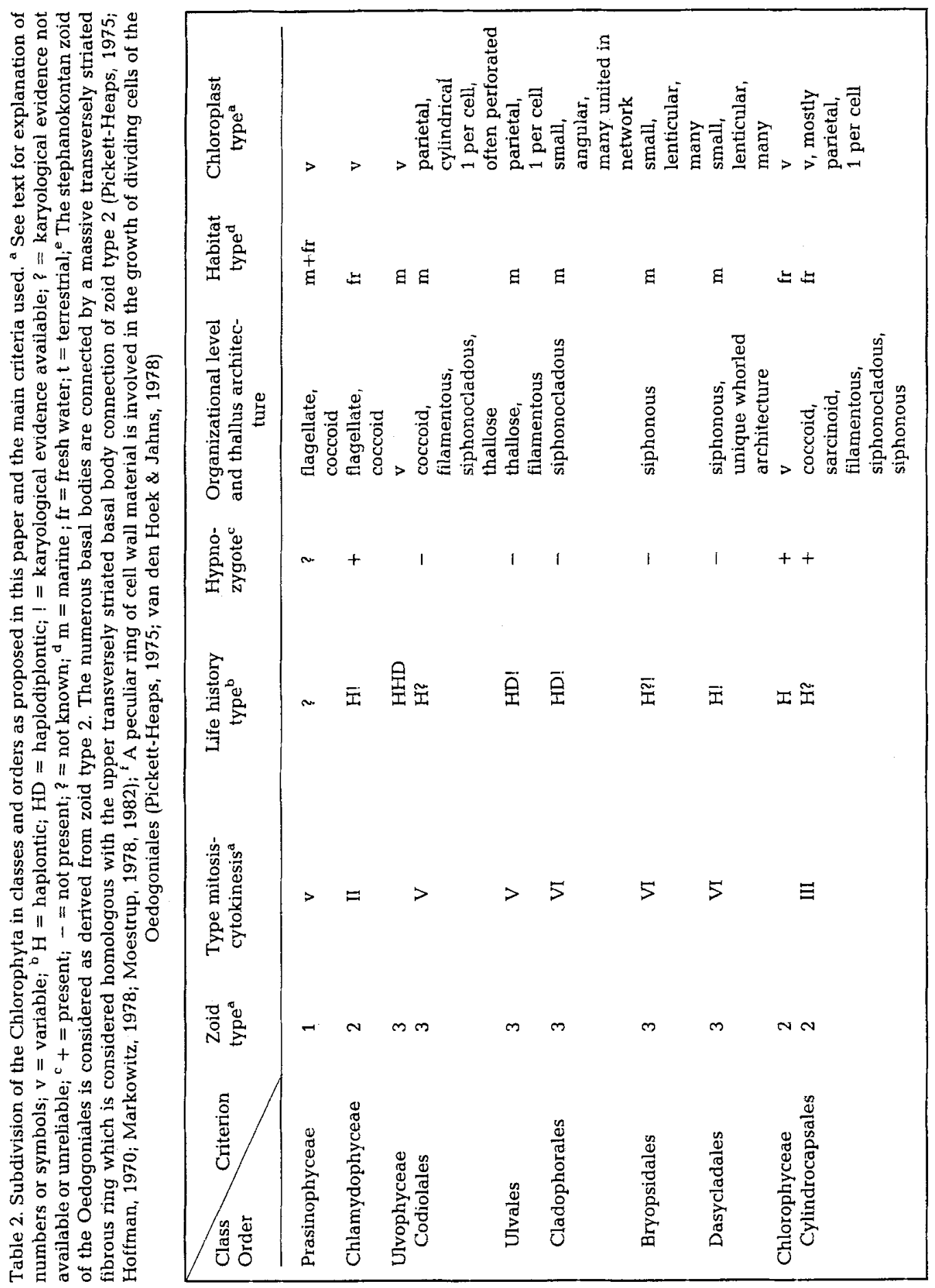




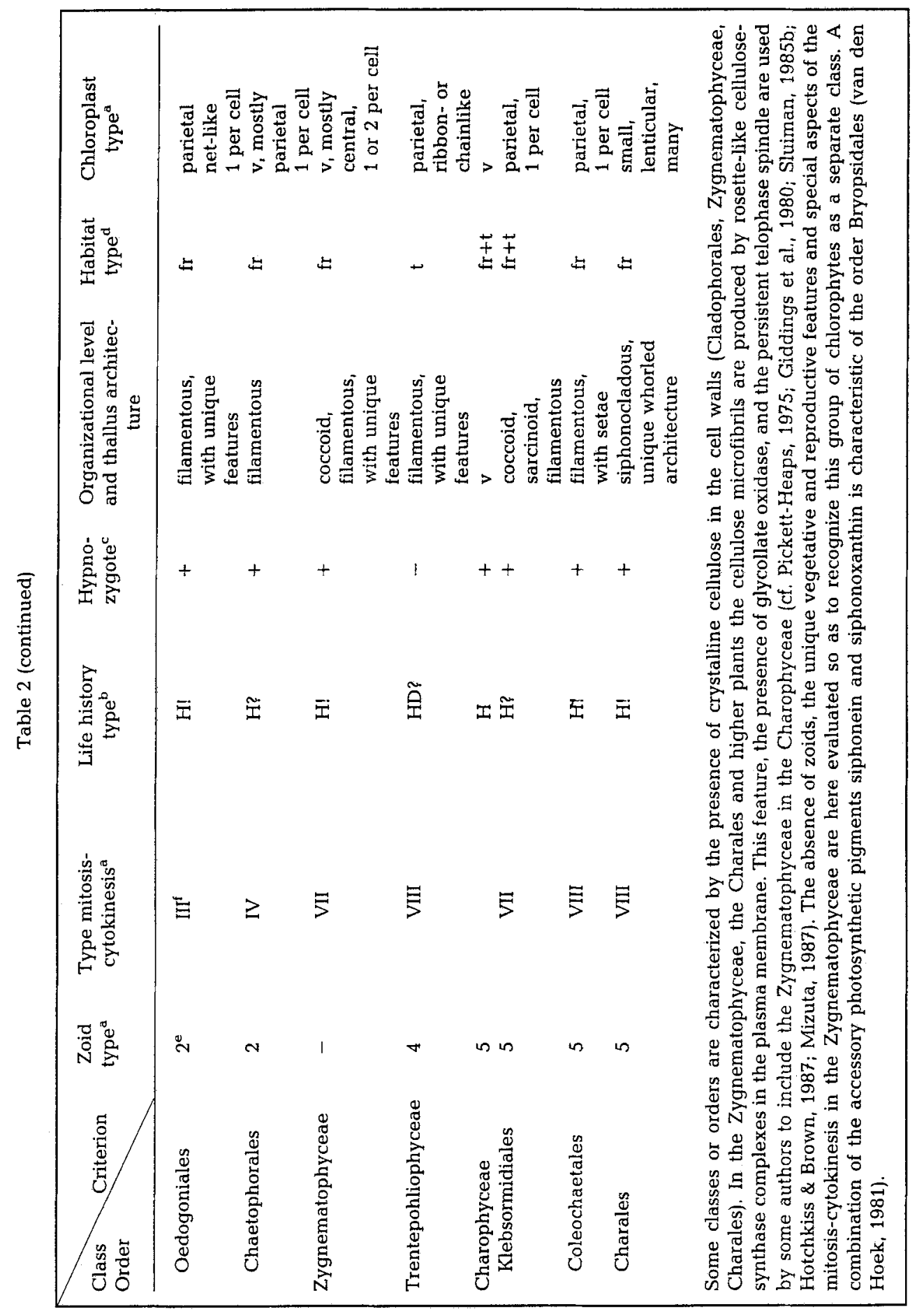



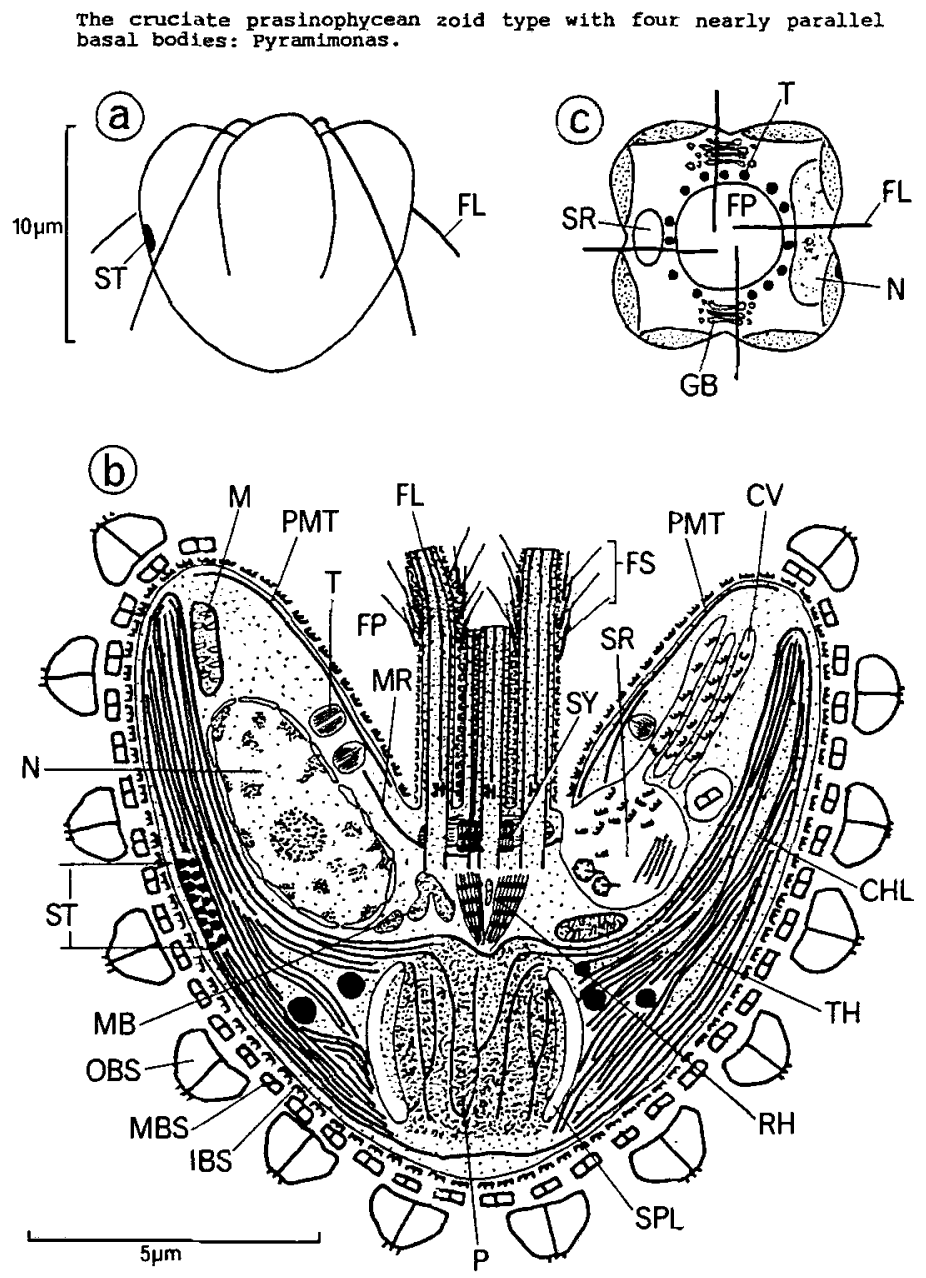

Fig. 2. Pyramimonas lunata, a zoid of the cruciate prasinophycean type (semidiagrammatic). a Light microscopic image; b Electron-microscopic inage; $\mathrm{c}$ Top view of cell. CHL-chloroplast; $\mathrm{CV}=$ cylindrical vesicle containing outer body scales formed in the Golgi apparatus; FL = flagellum; FP = flagellar pit; FS = flagellar scales; $\mathrm{GB}=$ Golgi body; $\mathrm{IBS}=$ inner layer body scales; $\mathrm{M}=$ mitochrondrion; $\mathrm{MB}=$ microbody; $\mathrm{MBS}=$ middle layer body scales; $\mathrm{MR}=$ microtubular root of flagellar apparatus; $\mathrm{N}=$ nucleus; $\mathrm{OBS}=$ outer layer body scales; $\mathrm{P}=$ pyrenoid; $\mathrm{PMT}=$ pit microtubules; $\mathrm{RH}=$ rhizoplast; $\mathrm{SPL}=$ starch plate on pyrenoid; $\mathrm{SR}=$ scale reservoir; $\mathrm{ST}=$ stigma; $S Y=$ synistosome; $T=$ trichocyst TH $=$ thylakoid (Based on Inouye et al., 1983)

The cells, when laterally viewed, are approximately bilaterally symmetrical. The flagellar basal bodies are anchored in the cell by four cruciately arranged microtubular roots when the cell is viewed on its tip (Fig. 5). Two opposite roots consist each of two microtubules, and the two remaining opposite roots each consist of a varying number (mostly 3-8) microtubules. This arrangement of the microtubular roots has been termed the X-2-X-2 pattern (Moestrup, 1978). When viewed on the tip of the cell, the two basal 


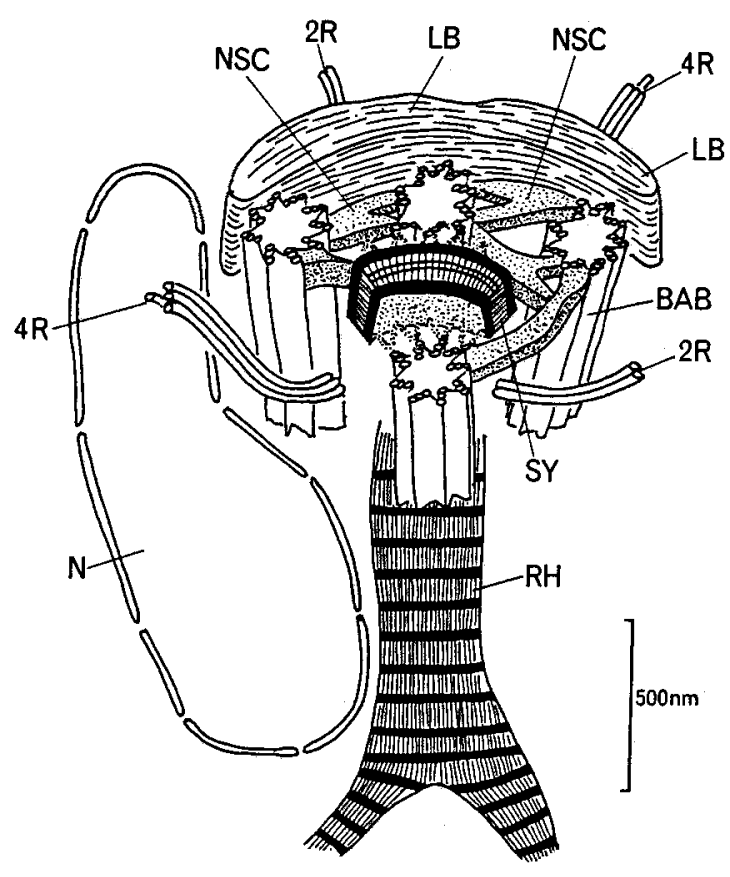

Fig. 3. Pyramimonas, diagram of the flagellar apparatus. $B A B=$ basal body of flagellum; $L B=$ lateral fibrous band; $\mathrm{N}=$ nucleus, $\mathrm{NSC}=$ nonstriated connective; $2-\mathrm{R}=2$-stranded microtubular root; 4-R = 4-stranded microtubular root; $S Y=$ synistosome (Based on Pienaar \& Aken, 1985)

bodies are not precisely in line with one another but take $10^{\prime} \mathrm{clock} / 7$ o'clock positions (Fig. 6).

Other ultrastructural features of the flagellar apparatus are also considered characteristic of this type; for instance, the possession of an upper transversely striated connective linking the basal bodies (Fig. 5). The basal bodies are each (at least in some species of Chlamydomonas and related genera) connected by a rhizoplast to the nuclear envelope (not indicated in Fig. 5). These rhizoplasts are much more delicate than those in the Prasinophyceae, and have apparently often been overlooked (cf. Eyden, 1975; Hyams \& Chasey, 1974; Lembi, 1975; Katz \& McLean, 1979; Melkonian \& Preisig, 1984). This flagellate cell type is considered characteristic of the Chlamydophyceae, a class of free living green flagellates (Ettl, 1981; Ettl \& Komàrek, 1982), and of the reproductive zoids in the class Chlorophyceae s.s. In contrast to Ettl $(1981,1983)$, we also include "naked" relatives of Chlamydomonas such as Dunaliella in the Chlamydophyceae. Dunaliella appears to be covered by a vestigial "wall" of glycoproteins which are also an important constituent of Chlamydomonas walls (Chardard, 1987). We agree with Ettl's including "near-flagellate" coccoid green algae, such as Chlorococcum, in the Chlamydophyceae. (A selection of references for Chlamydophyceae; Brown et al., 1976; Goodenough \& Weiss, 1978; Greuel \& Floyd, 1985; Hoops , 1984; Hoops \& Floyd, 1983; Katz \& McLean, 1979; Lembi, 1980; Melkonian \& Preisig, 1984; Moestrup, 1978, 1982; O'Kelly \& Floyd, 1984; and for Chlorophyceae: Buchheim \& Hoffmann, 1986; Floyd \& Hoops, 1980; Floyd 


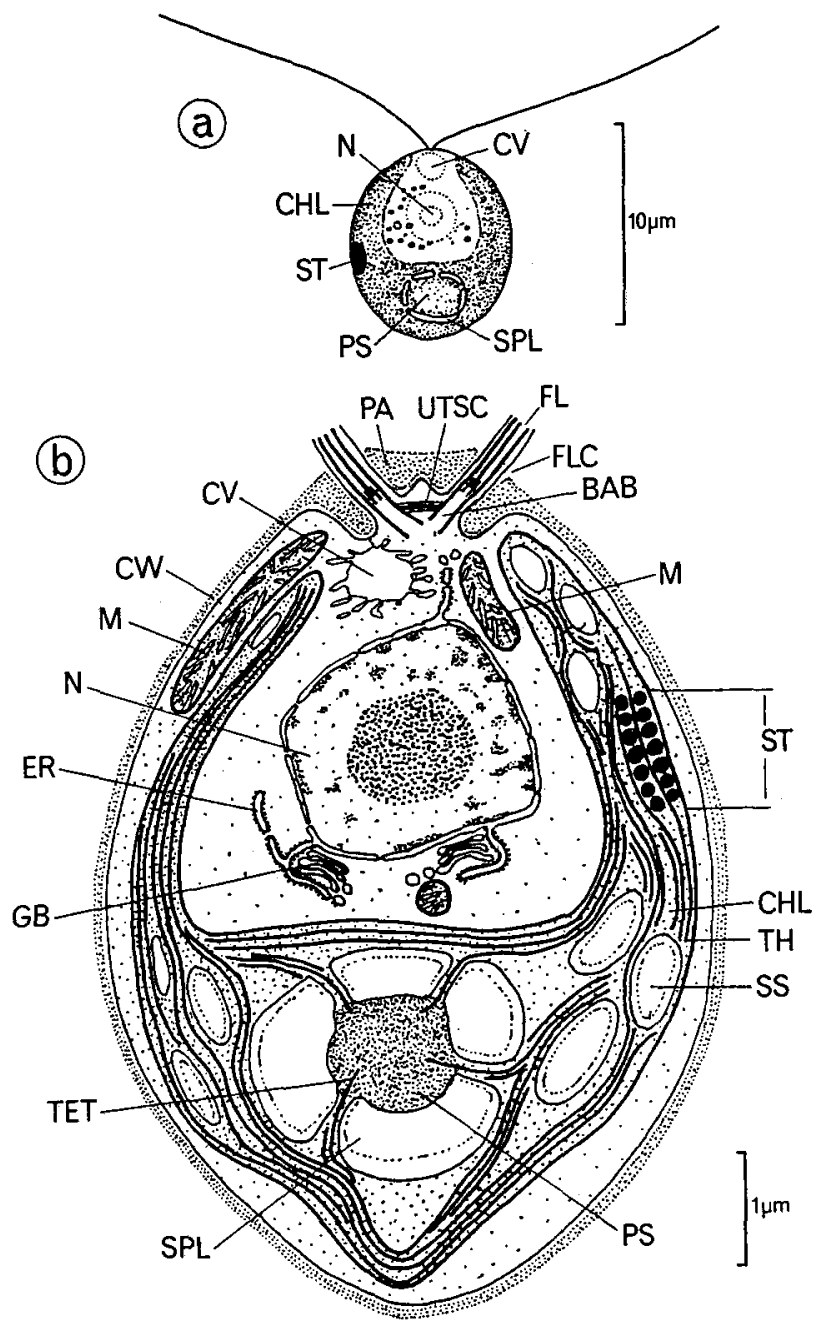

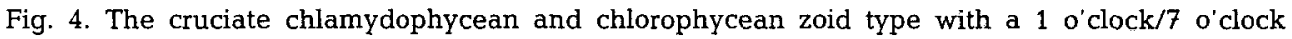
configuration of the two basal bodies: Chlamydomonas. a Light microscope image; $b$ Electron microscopic image, schematic $(\mathrm{BAB}=$ basal body of flagellum; $\mathrm{CHL}=$ chloroplast $\mathrm{CV}=$ contractile vacuole $; \mathrm{CW}=$ cell wall $; \mathrm{ER}=$ endoplasmic reticulum; FL = flagellum; $\mathrm{FLC}=$ flagellar channel $\mathrm{GB}$ $=$ Golgi body; $\mathrm{M}=$ mitochondrion; $\mathrm{N}=$ nucleus; $\mathrm{PA}=$ apical papilla; $\mathrm{PS}=$ pyrenoid stroma; $\mathrm{SPL}=$ starch plate on pyrenoid; SS = stroma starch; $\mathrm{ST}=$ stigma; $\mathrm{TET}=$ tubular extension of thylakoid in pyrenoid; $\mathrm{TH}=$ thylakoid; UTSC = upper transversely striated connective between the basal bodies). (a Based on Ettl, 1976; b on Ringo, 1967)

et al., 1980; Hoffmann, 1984; Melkonian, 1977, 1978, 1983; Moestrup, 1978, 1982; O'Kelly \& Floyd, 1984).

(3) Flagellate cells of the cruciate type with an 11 o'clock/5 o'clock configuration of the flagellar apparatus (Figs 6, 7).

This type is rather similar to the previous type, apart from the 11 o'clock/5 o'clock 


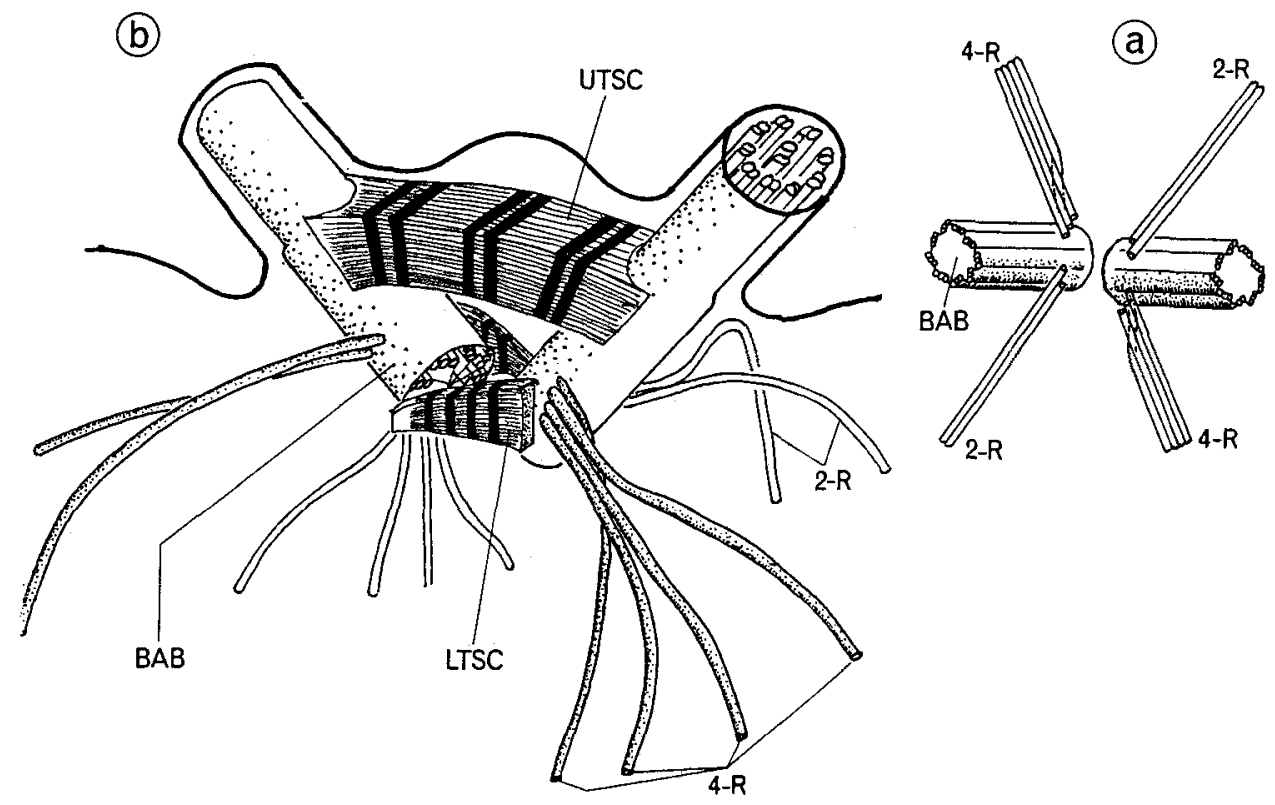

Fig. 5. Flagellar apparatus of a cruciate chlamydophycean and chlorophycean zoid-type with a 1 o'clock/7 o'clock configuration of the basal bodies: Chiamydomonas. a Spatial top view of the two basal bodies (BAB) and the four microtubular roots; b Spatial side view of the two basal bodies (BAB), the four microtubular roots, the upper transversely striated connective (UTSC) and the two lower transversely striated connectives (LTSC) between the basal bodies. (4-R $=4$-stranded microtubular root; $2-\mathrm{R}=2$-stranded microtubular root). (a Based on Mattox \& Stewart, 1984; b original)

positions of the basal bodies and the overlap of the two basal bodies with attached microtubular roots. Other ultrastructural features of the flagellar apparatus are also considered characteristic of this type, although they vary among the orders having this type. Examples are the possession of an upper non-striated connective linking the basal bodies (sometimes it is striated), and the possession of terminal caps on the lower ends of the basal bodies. (A selection of references: Bakker \& Lokhorst, 1985; Floyd \& O'Kelly, 1984; Floyd et al., 1985; Gori, 1979; Hirayama \& Hori, 1984; Hoops et al,, 1982; Hori, 1977; Hori \& Kobara, 1982; Jónsson \& Chesnoy, 1984; Lokhorst, 1984; Melkonian, 1979, 1980, 1981b; Miyaji \& Hori, 1984; O'Kelly \& Floyd, 1983; O'Kelly et al., 1984; Roberts et al., 1980, 1981, 1982; Sluiman, 1985b; Sluiman et al., 1980b, 1982; Stuessy et al., 1983). This flagellate cell type is characteristic of the class Ulvophyceae.

(4) Flagellate cells strongly compressed, of the cruciate type, with an $110^{\prime}$ clock/5 o'clock configuration of the flagellar apparatus, and with columnar structures associated with the basal bodies.

This type has additional special features. It characterizes the class Trentepohliophyceae. (A selection of references: Chapman, 1981, 1984; Chapman \& Henk, 1983, 1985; Graham, 1984; Graham \& McBride, 1975; Roberts, 1984).

(5) Flagellate cells of the unilateral type (Fig. 8).

The flagella are not apically, but laterally implanted. The flagella are anchored in the cell by one broad unilateral band of many microtubules. Near the basal bodies this 


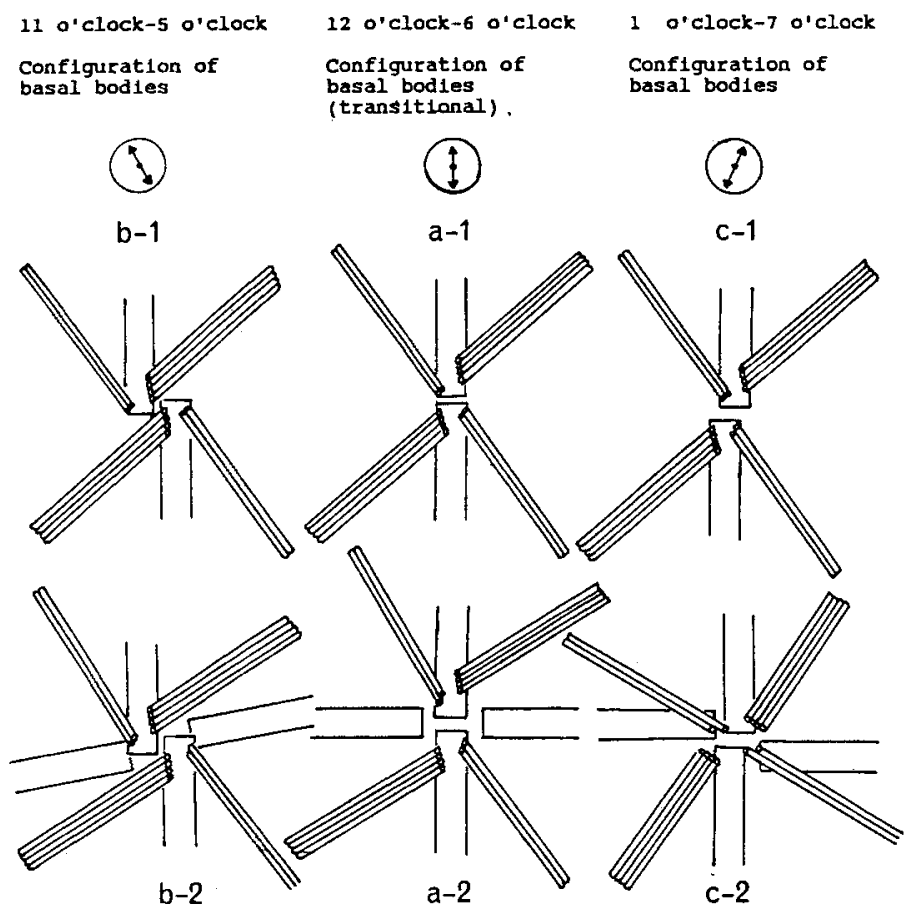

Fig. 6. Cruciate microtubular root systems of flagellar apparatuses in green algae (diagram). Top view of basal bodies with two- and four-membered microtubular roots. a-1, b-1, c-1 in biflagellate zoids; $a-2, b-2, c-2$ in quadriflagellate zoids. a-1: Hypothetical ancestral configuration, the basal bodies take a $12 \mathrm{o}^{\prime}$ clock and $6 \mathrm{o}^{\prime}$ clock position. b-1: The basal bodies take a mutually slightly overlapping, 11 o'clock and a 5 o'clock position. c-1: The basal bodies take a 1 o'clock and a, non overlapping, 7 o'clock position (Based on O'Kelly \& Floyd, 1984; Mattox \& Stewart, 1984)

microtubular band is incorporated in a multilayered structure (MLS). Apart from the microtubular layer, two laminate layers compose the MLS (Moestrup 1974, 1982).

The unilateral zoid type is deemed characteristic of the class Charophyceae and of the mosses and vascular plants. (A selection of references: Graham \& McBride, 1979; Graham \& Wedemeyer, 1984; Marchant et al., 1973; Moestrup, 1970, 1974, 1982; PickettHeaps, 1975; Rogers et al., 1980; Sluiman, 1983, 1985b).

A sixth type of flagellate reproductive cell has an $110^{\circ}$ clock $/ 5$ o'clock configuration of the flagellar apparatus (as in the Ulvophyceae). The strongly compressed cells have the usual X-2-X-2 pattern of microtubular roots. The tips of the X-roots overlie a faintly layered structure with some resemblance to the MLS of the unilateral zoids. Possibly this flagellate cell type characterizes another chlorophytan class, the Pleurastrophyceae. (Selected references: Mattox \& Stewart, 1984; Melkonian \& Berns, 1983; Sluiman, 1985b; Deason \& Floyd, 1987).

\section{Type of mitosis-cytokinesis}

The processes of mitosis and cytokinesis are thought to provide evolutionary old characters, as all eukaryotes need these processes for a precise distribution of identical 
(a)
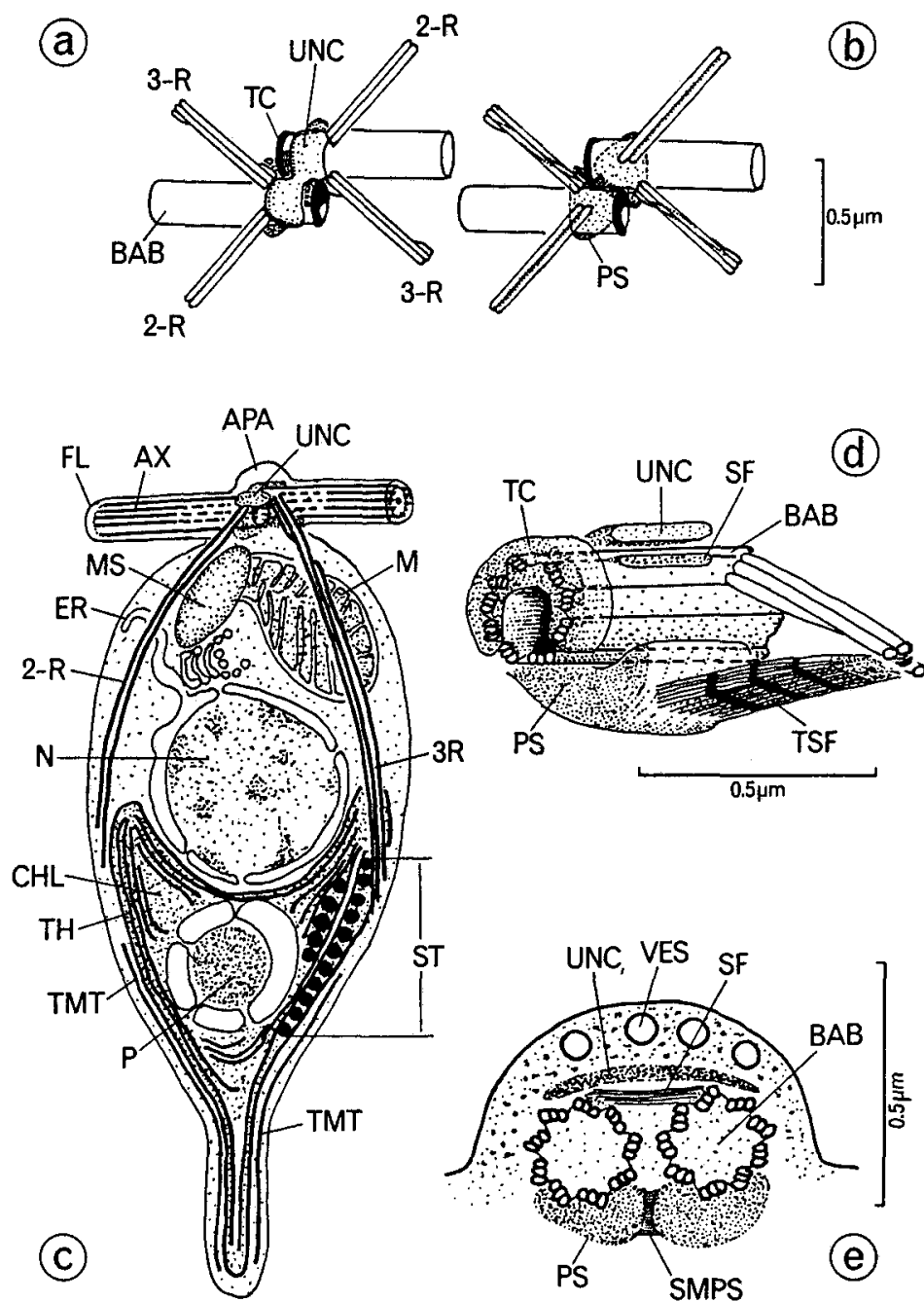

(d)

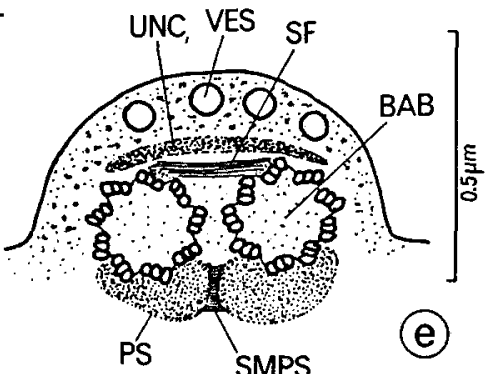

Fig. 7. The cruciate ulvophycean zoid type with an 11 o'clock/5 o'clock configuration of the two basal bodies: the gamete of Acrosiphonia. a Top view of flagellar apparatus, basal bodies pictured as cylinders (diagram); b Idem, the lower parts of the flagellar apparatus are shown through the transparent basal bodies; c Electron microscopical side view of the whole gamete (diagram); d side view of basal body showing one of the two tranversely striated fibres connecting one of the two three-stranded microtubular roots with one of the two proximal (lower) sheaths (diagram); e Longitudinal section through the apical papilla in the plane perpendicular to that of Figure $7 \mathrm{C}$. APA $=$ apical papilla; $\mathrm{AX}=$ axoneme; $\mathrm{BAB}=$ basal body; $\mathrm{CHL}=$ chloroplast $; \mathrm{ER}=$ endoplasmic reticulum; $F L=$ flagellum; $M=$ mitochondrion; $M S=$ mating structure $; N=$ nucleus; $P=$ pyrenoid; PS = proximal $(=$ lower $)$ sheath; $2-\mathrm{R}=$ two-stranded microtubular root; $3-\mathrm{R}=$ three-stranded microbutular root; $\mathrm{SF}=$ tiny second (striated) fibre connecting basal bodies; SMPS $=$ striated material connecting the two proximal (lower) sheaths; ST = stigma; TC = terminal cap (partly closing the basal end of the basal body) ${ }_{i} \mathrm{TH}=$ thylakoid; $_{i} \mathrm{TMT}=$ tail microtubule; TSF $=$ one of two transversely striated fibres connecting one of the two three-stranded microtubular roots with one of the proximal sheaths; UNC = upper non-striated connective between the basal bodies; VES = vesicles probably with sticky material for attachment of zoid (Based on Miyaji \& Hori, 1984) 


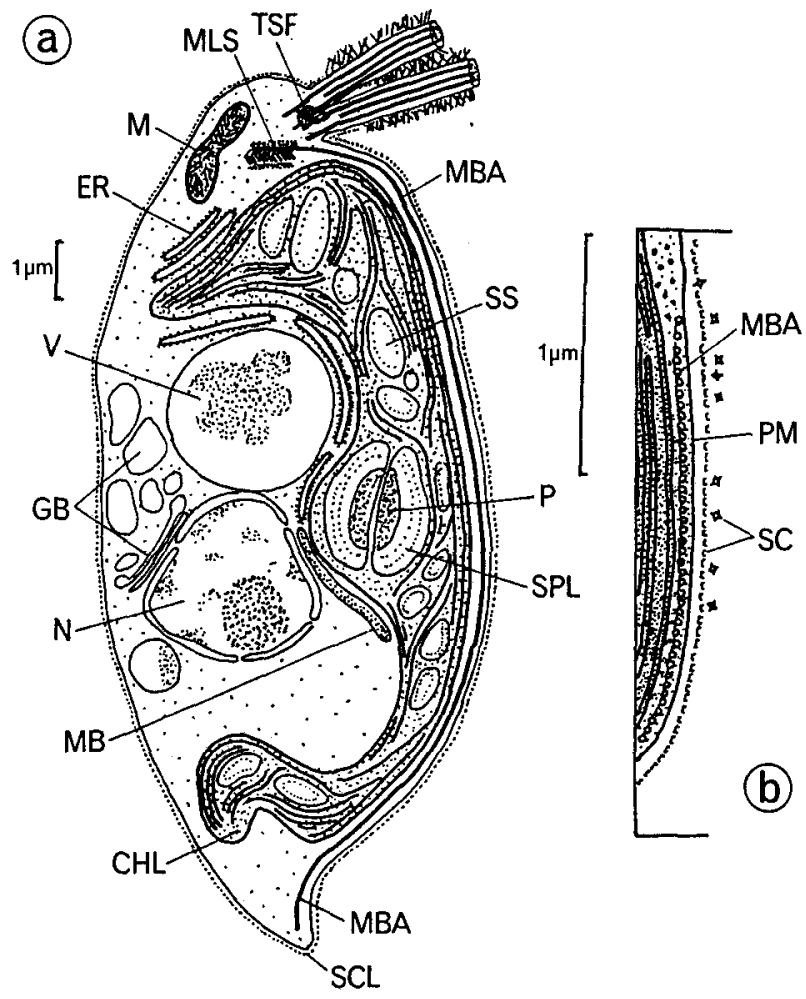

Fig. 8. The unilateral charophycean zoid type with a broad lateral band of microtubules and a MLS (multilayered structure): the Chaetosphaeridium zoospore. a Longitudinal section; $b$ transverse section of the microtubular band of the flagellar apparatus. $\mathrm{CHL}=$ chloroplast $\mathrm{ER}=$ endoplasmic reticulum; $\mathrm{GB}=$ Golgi body; $\mathrm{M}=$ mitochondrion; $\mathrm{MB}=\operatorname{microbody} ; \mathrm{MBA}=$ microtubular band of flagellar apparatus; $N=$ nucleus; $M L S=$ multilayered structure; $\mathrm{P}=$ pyrenoid; $\mathrm{SC}=$ layer of organic diamond scales; SPL = starch plate on pyrenoid; SS = stroma starch; TSF = transversely striated fibre connecting basal bodies; $V=$ vacuole (Based on Moestrup, 1974; van den Hoek, 1981)

genomes and sets of organelles over two daughter cells during nuclear and cellular division.

At least eight different types of mitosis-cytokinesis can be discerned in the Chlorophyta. Only the most prominent features will be briefly mentioned.

I. Open mitosis with a persistent telophase spindle; cytokinesis by a cleavage furrow of the plasma membrane. The two spindle poles each consist of a set of basal bodies with a rhizoplast (Fig. 9, top).

This type is exhibited by the prasinophycean Pyramimonas. Nephroselmis, a prasinophycean with two unilaterally implanted flagella, has a similar type of mitosiscytokinesis which is, however, closed (i.e. the nuclear envelope is largely retained during mitosis) (Fig. 18, type Ia) (Mattox \& Stewart, 1977; Pearson \& Norris, 1975; Woods \& Triemer, 1981).

II. Closed mitosis with a non-persistent telophase spindle (i.e. the spindle collapses early at telophase so that the daughter nuclei approach one another closely); cytokinesis 
(a)

(b.)

(C)
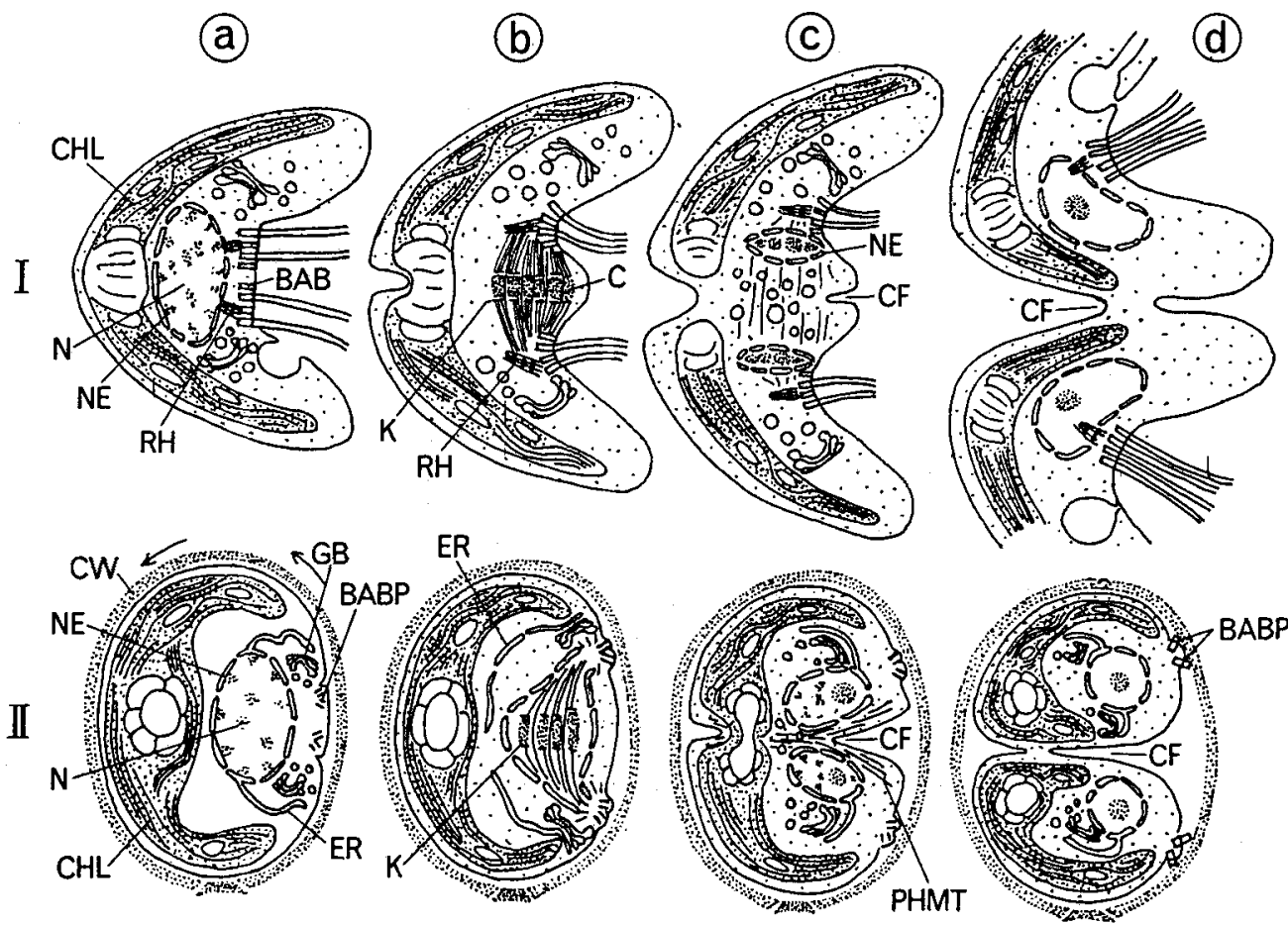

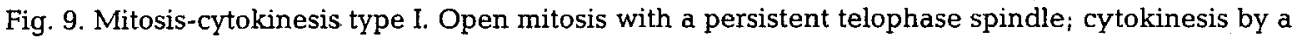
cleavage furrow (Pyramimonas). Mitosis-cytokinesis type II. Closed mitosis with a non-persistent telephase spindle; cytokinesis by a cleavage furrow in a phycoplast (Chlamydomonas). a Early prophase; b Metaphase; c Late telophase; d Early interphase. Arrows indicate $90^{\circ}$ rotation of dividing cell within parent cell wall. $\mathrm{BAB}=$ basal body; $\mathrm{BABP}=$ pair of basal bodies; $\mathrm{C}=$ chromosone; $\mathrm{CF}=$ cleavage furrow; $\mathrm{CHL}=$ chloroplast; $\mathrm{CW}=$ cell wall; $\mathrm{ER}=$ endoplasmic reticulum; $\mathrm{GB}=$ Golgi body; $\mathrm{K}=$ kinetochore $\mathrm{N}=$ nucleus; $\mathrm{NE}=$ nuclear envelope; $\mathrm{PHMT}=$ phycoplast microtubule; $\mathrm{RH}=$ rhizoplast (I based on Woods \& Triemer, 1981; II based on Triemer \& Brown, 1974)

by a cleavage furrow of the plasma membrane in a phycoplast (i.e. a plate of microtubules in the division plane). The two spindle poles each consist of a set of basal bodies (Fig. 9, bottom).

This type is exhibited by Chlamydophyceae (Lembi, 1980; Triemer \& Brown, 1974; Pickett-Heaps, 1975).

III. Closed mitosis with a non-persistent telophase spindle; cytokinesis by a cell plate of smooth endoplasmic reticulum (ER) vesicles, in a phycoplast (Fig. 10, top).

A cell plate is a plate of vesicles in the division plane which coalesce to form the transverse septum dividing the two daughter cells. After completion of the transverse septum the Golgi-bodies secrete a new cell wall around each daughter protoplast (Fig. 10 , top).

This is the type of mitosis-cytokinesis which is probably exhibited by many coccoid, but also by sarcinoid and filamentous green algae (Sluiman, 1984, 1985a, b). 
(a)

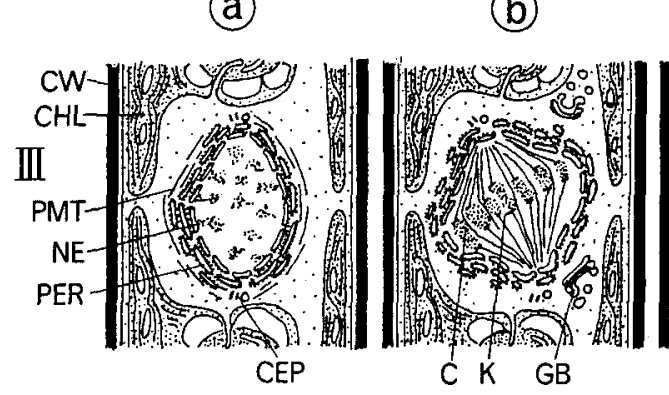

(C)

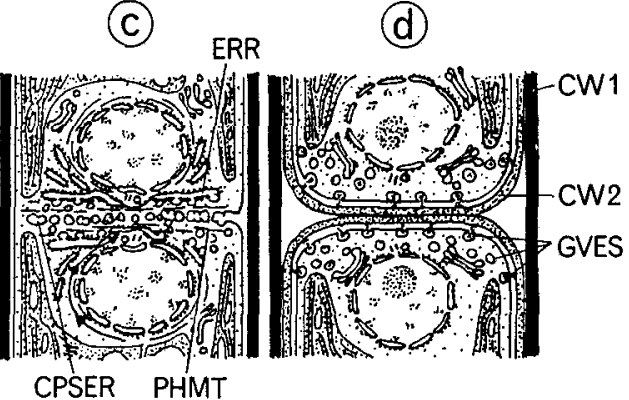

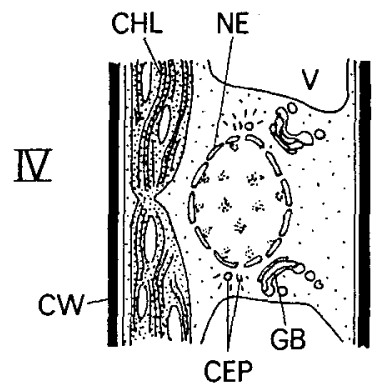
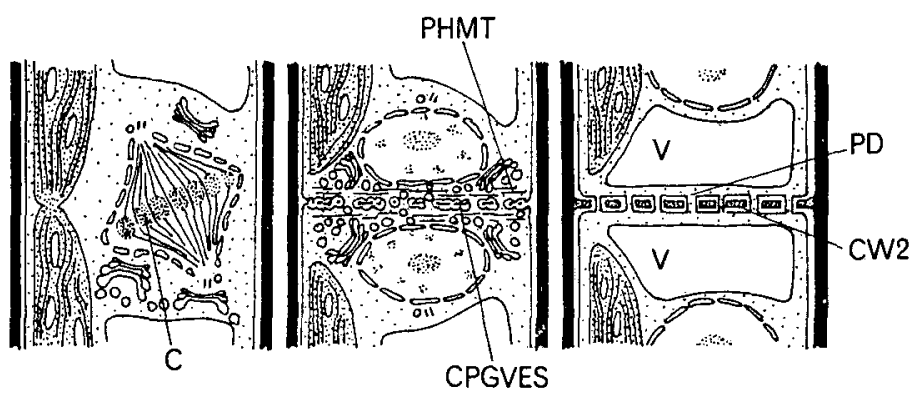

Fig. 10. Mitosis-cytokinesis type III. Closed mitosis with a non-persistent spindle; cytokinesis by a cell plate of smooth ER-vesicles in a phycoplast (Cylindrocapsa). Mitosis-cytokinesis type IV. Closed mitosis with a non-persistent telophase spindle; cytokinesis by a cell plate of Golgi-derived vesicles in a phycoplast (Uronema). a Early prophase; b Metaphase; $\mathrm{c}$ Late telophase; d Early interphase. $\mathrm{C}=$ chromosome $; \mathrm{CHL}=$ chloroplast $; \mathrm{CEP}=$ pair of centrioles $; \mathrm{CPGVES}=$ cell plate of Golgiderived vesicles $; \mathrm{CPSER}=$ cell plate of smooth $\mathrm{ER}$-vesicles; $\mathrm{CW}=$ cell wall $; \mathrm{CW} 1=$ old cell wall; $\mathrm{CW} 2=$ young cell wall; $\mathrm{ERR}=$ rough endoplasmic reticulum; $\mathrm{GB}=$ Golgi body; GVES = Golgiderived vesicles; $\mathrm{K}=$ kinetochore $\mathrm{MB}=$ microbody; $\mathrm{MTLEF}=$ microtubules along leading edge of cleavage furrow of plasma membrane; $\mathrm{NE}=$ nuclear envelope $; \mathrm{PD}=$ plasmodesma; $\mathrm{PER}=$ perinuclear endoplasmic reticulum; PHMT $=$ phycoplast microtubules; PHRM $=$ phragmoplast microtubule; PMT = perinuclear microtubules; $\mathrm{V}=$ vacuole (III based on Sluiman, 1984, 1985a; IV on Floyd et al., 1972b)

IV. Closed mitosis with a non-persistent telophase spindle; cytokinesis by a cell plate of Golgi-derived vesicles in a phycoplast (Fig. 10, bottom).

The Golgi-derived cell plate vesicles contain cell wall material. Coalescence of the vesicles results in the formation of the transverse cell wall which remains traversed by plasmodesmata between the daughter cells.

Certain filamentous representatives of the class Chlorophyceae have this type of mitosis-cytokinesis (Floyd et al., 1972a; Mattox et al., 1974; McBride, 1967, 1970; PickettHeaps, 1975).

V. Closed mitosis with a persistent telophase spindle; cytokinesis by a cleavage furrow of the plasmamembrane to which Golgi-derived vesicles are added (Fig. 11, top). The new cross wall is not traversed by plasmodesmata. Neither a pronounced phycoplast (Types III, IV) nor a pronounced phragmoplast (Type VIII) are involved in cytokinesis.

This type of mitosis-cytokinesis is encountered in filamentous thallose and some 
(a)
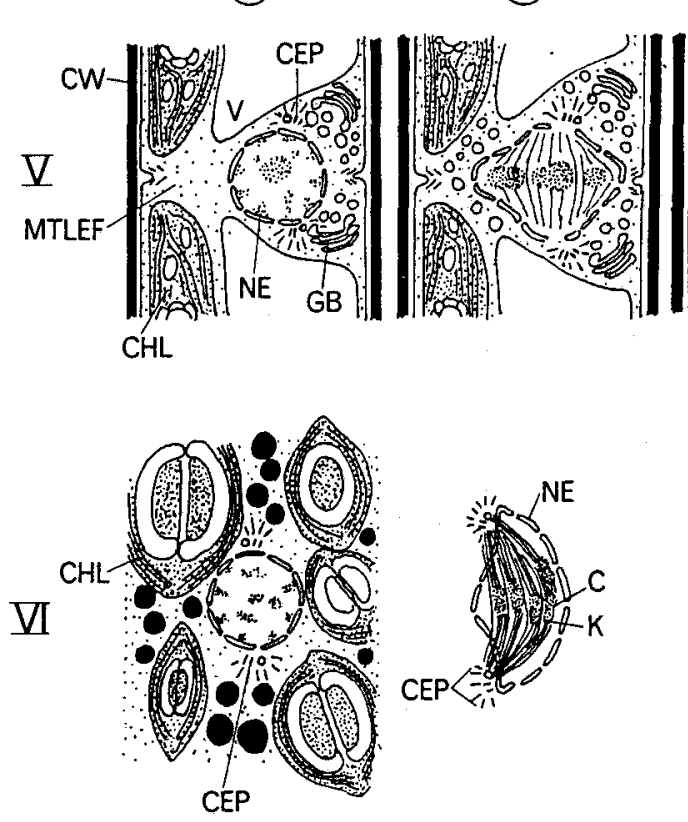

(c)

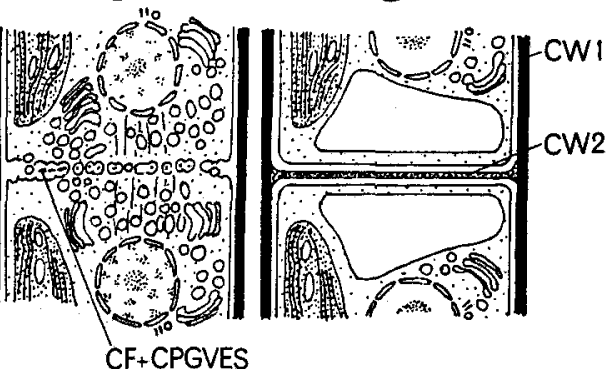

(d)

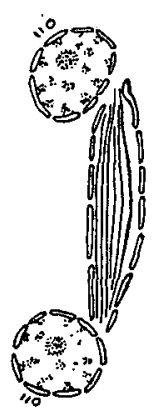

Fig. 11. Mitosis-cytokinesis type V. Closed mitosis with a persistent telophase spindle; cytokinesis by a cleavage furrow to which Golgi-derived vesicles are added (Ulothrix). Mitosis-cytokinesis type VI. Closed mitosis with a prominent persistent telophase spindle, causing a typical dumb-bell shape; cytokinesis does not immediately follow mitosis (Valonia). For abbreviations, see text to Figure 10 (V based on Sluiman et al,, 1983; VI on Hori \& Enomoto, 1978b)

siphonocladous Ulvophyceae (Hudson \& Waaland, 1974; Lokhorst, 1984, 1985; Lokhorst \& Star, 1983; Løvlie \& Bråten, 1968, 1970; McArthur \& Moss, 1978; Sluiman et al., 1983).

VI. Closed mitosis with a prominent persistent telophase spindle giving the telophase nucleus a typical dumbbell-shape; cytokinesis does not immediately follow mitosis (Fig. 11 , bottom).

This type is characteristic of most siphonocladous, and of siphonous Ulvophyceae (Burr \& West, 1970; Hori, 1981; Hori \& Enomoto, 1978a, 1978b; Liddle et al., 1976; McDonald \& Pickett-Heaps, 1976; Scott \& Bullock, 1976).

VII. Open mitosis with a prominent persistent telophase spindle; cytokinesis by a cleavage furrow of the plasma membrane. The cross wall is not traversed by plasmodesmata (Fig. 12, top).

This type of mitosis-cytokinesis is characteristic of the simplest representatives of the class Charophyceae (Chappell \& Floyd, 1981; Floyd et al., 1972b; Lokhorst \& Star, 1985; Lokhorst, 1987; Pickett-Heaps, 1972, 1974, 1975, 1976).

VIII. Open mitosis with a prominent persistent telophase spindle; cytokinesis by a cell plate of Golgi-derived vesicles in a phragmoplast. A phragmoplast is the complex of old spindle microtubules plus new peripherally added microtubules that are parallel to the spindle (Fig. 12, bottom). 
(a)

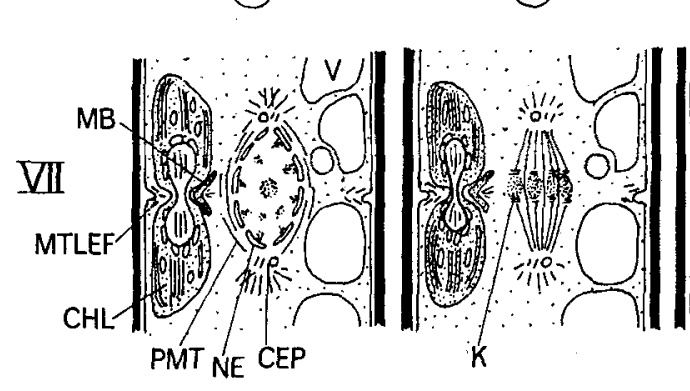

(C)

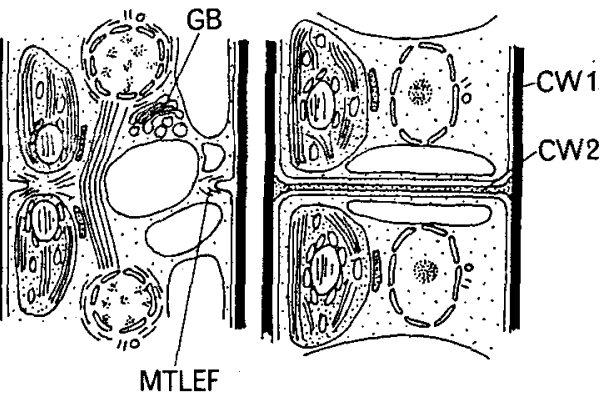

(d)

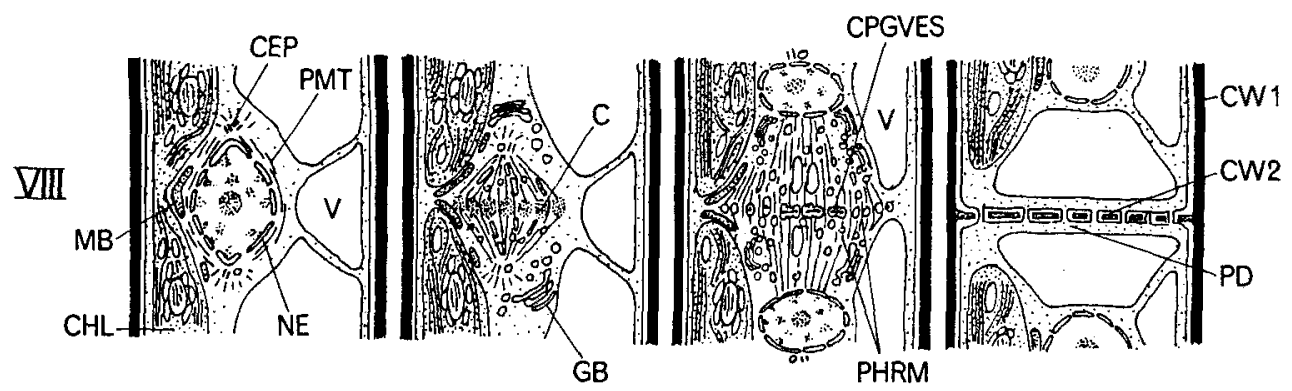

Fig. 12. Mitosis-cytokinesis type VII. Open mitosis with a prominent persistent telophase spindle; cytokinesis by a cleavage furrow (Klebsormidium). Mitosis-cytokinesis type VIII. Open mitosis with a prominent persistent telophase spindle; cytokinesis by a cell plate of Golgi-derived vesicles in a phragmoplast. For abbreviations, see text to Figure 10 (VII based,on Lokhorst \& Star, 1985; VIII on Marchant \& Pickett-Heaps, 1973)

The Golgi-derived vesicles contain cell wall material and are arranged in a cell plate, "guided" by the phragmoplast. Their coalescence results in the formation of the cross wall which remains traversed by plasmodesmata.

This type of mitosis-cytokinesis is characteristic of the more sophisticated representatives of the class Charophyceae, of the mosses and vascular plants, and of the Trentepohliophyceae (Chapman \& Good, 1978; Chapman \& Henk, 1986; Marchant \& Pickett-Heaps, 1973; Pickett-Heaps, 1975).

Place of meiosis in the life history and, consequently, the sexual life history type

Meiosis is thought to have arisen in the early history of the primaeval eukaryotes. In its ultrastructural details (e.g. the synaptonemal complexes), meiosis is similar in very divergent eukaryotes. Therefore, the place of meiosis and the related sexual life history are thought to potentially provide conservative characters. According to this reasoning, sexual reproduction has arisen only once in eukaryotan evolution, but it has been secondarily lost in the numerous eukaryotes lacking sexual reproduction.

Our knowledge on life histories is still deficient for many green algal groups, expecially with regard to the ploidy levels of the different life history stages and the position of meiosis. On the basis of the evidence available it would seem that the majority of green algal groups have an haplontic life history with only the zygote nucleus being 
diploid. Only in the fresh-water classes Chlamydophyceae, Chlorophyceae and Charophyceae are the zygote nuclei encased in hypnozygotes. These are probably an adaptation to life in freshwater, and serve for survival after desiccation of water bodies or during transport from one freshwater body to the other. The geologically ephemeral nature of freshwater bodies in comparison to the world ocean should be recalled.

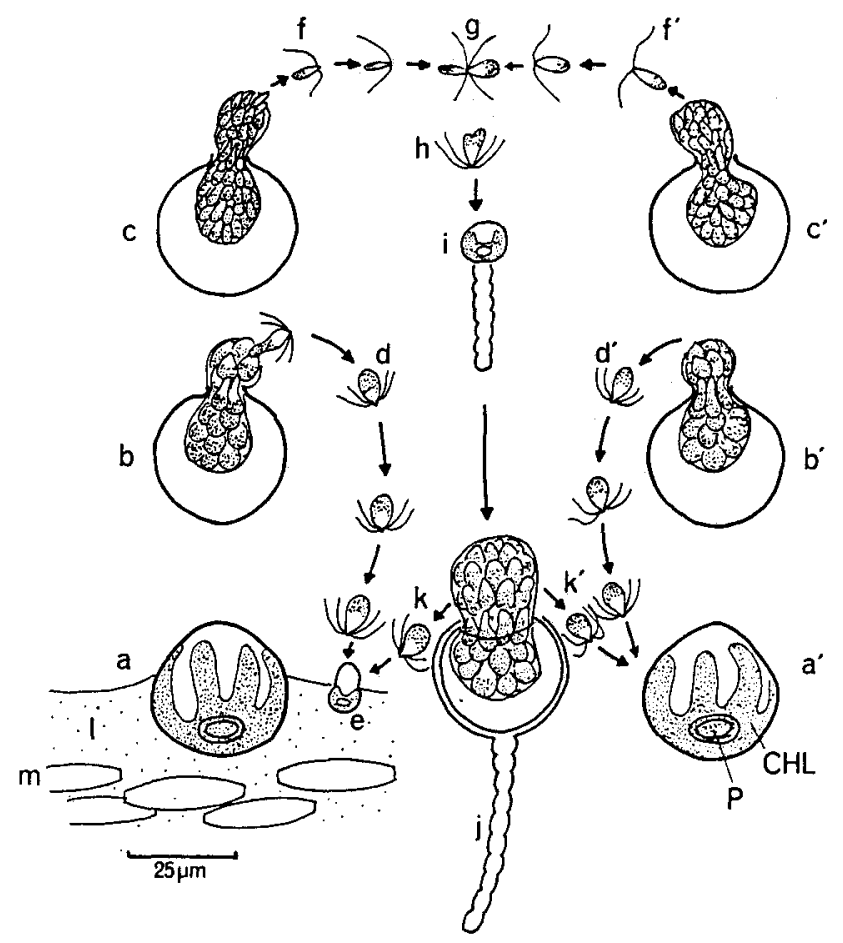

Fig. 13. Chlorocystis cohnii (Ulvophyceae, Codiolales), life history. $a, a^{1}$ Gametophyte; $b, b^{1}$ the cell contents have divided into quadriflagellate asexual spores; $c, c^{1}$ the cell contents have divided into biflagellate anisogametes; $d, d^{1}$ asexual quadriflagellate zoopores; e germling; $f$ male gametes; $f^{1}$ female gametes; $g$ copulation; h planozygote; i young zygote; $\mathrm{j}$ full-grown, stalked, Codiolum-like zygote; $\mathrm{k}, \mathrm{k}^{1}$ quadriflagellate zoospores, presumably meiospores; 1 gelatinous matrix of tube forming diatom $(\mathrm{m}) . \mathrm{CHL}=$ chloroplast, $\mathrm{P}=$ pyrenoid. $($ Based on Kornmann \& Sahling, 1983)

The (presumably) haplontic life history of the order Codiolales (class Ulvophyceae) with a Codiolum-like zygote stage is highly characteristic of this order (Figs 13, 14). Dr. Kornmann has reiterated the phylogenetic importance of this character. His proposal (Kornmann 1963,1973) to regard the green algae with this type of life history as a taxon of high hierarchical level (order, class) was only rarely followed because the organizational levels contained in this taxon are very divergent and range from coccoid unicellular to branched siphonocladous and even thallose. Recent ultrastructural studies on the reproductive flagellate cells (Floyd \& O'Kelly, 1984; Jónsson \& Chesnoy, 1984; Miyaji \& Hori, 1984; Sluiman et al., 1980b, 1982) and the processes of mitosis and cytokinesis (Hudson \& 


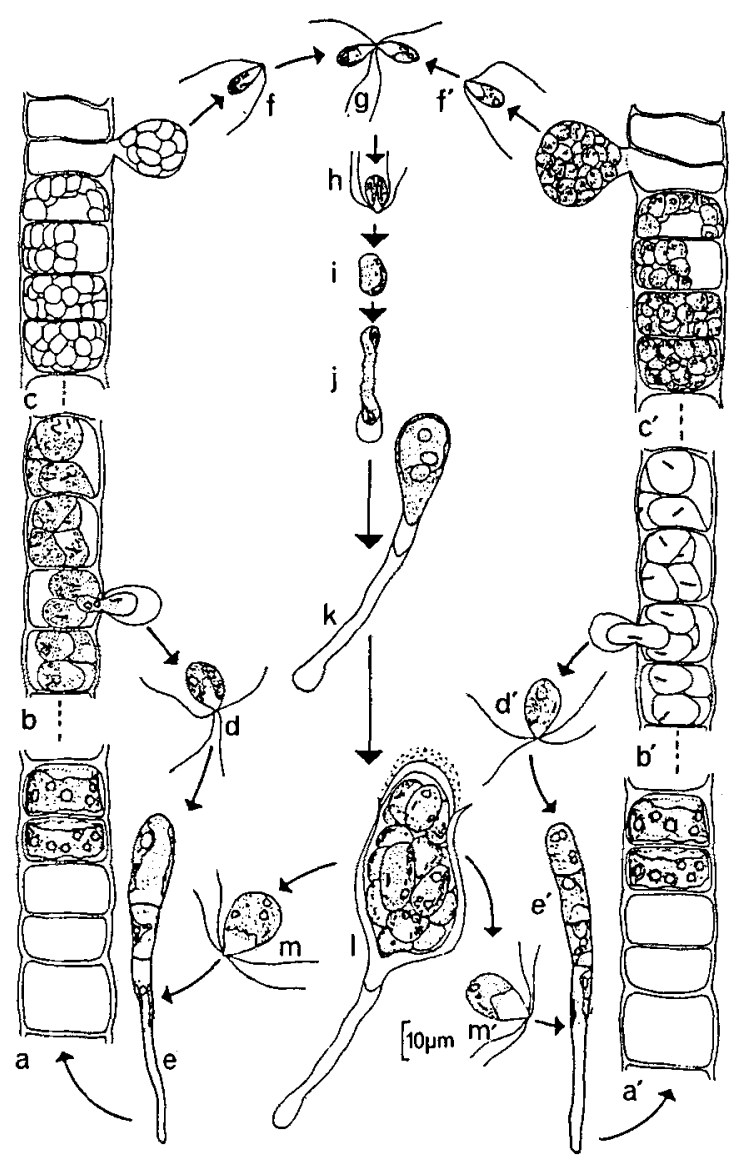

Fig. 14. Ulothrix zonata (Ulvophyceae, Codiolales), life history. $a, a^{1}$ Gametophyte; $b, b^{1}$ the cell contents have divided into quadriflagellate asexual zoospores; $c, c^{1}$ the cell contents have divided into biflagellate isogametes; $d, d^{1}$ asexual quadriflagellate zoospores; $e, e^{1}$ germlings; $f, f^{1}, g$ copulation of isogametes; $h$ planozygote; $i, j$ young zygote; $k, 1$ older, Codiolum-like zygote; $m_{1} m^{1}$ quadriflagellate zoospores, presumably meiospores (Based on Lokhorst \& Vroman, 1972)

Waaland, 1974; Lokhorst, 1984, 1985; Lokhorst \& Star, 1983; Sluiman et al., 1983) have confirmed the validity of Dr. Kornmann's proposal. The orders Dasycladales and Bryopsidales have long been considered as being fundamentally diplontic and as having gametic meiosis. At present, the early karyological evidence is questioned (Tanner, 1981; van den Hoek, 1981). Recent studies (Koop, 1975, 1979; Spring et al., 1978; Kloppstech, 1982; Shihira-Ishikawa \& Kuroiwa, 1984; Liddle et al., 1976) have produced evidence that only the giant zygote nucleus in the Dasycladalean life history is diploid (Fig. 15). This diploid nucleus is contained in a young, at first spherical, stage. Later on, the adult plant develops from this young stage, and it receives numerous haploid nuclei after vegetative meiosis of the giant zygote nucleus.

The life histories in the related order Bryopsidales seem to be rather similar for they include young zygote stages with giant zygote nuclei, for instance in Udotea (Meinesz, 


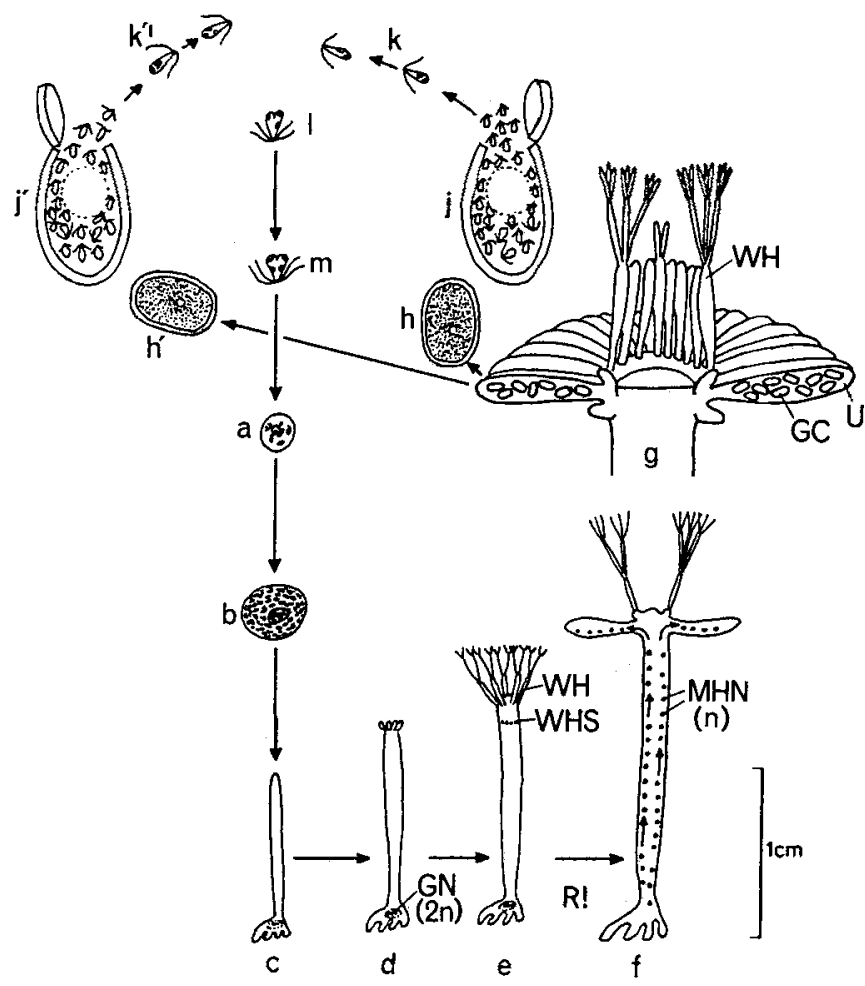

Fig. 15. Acetabularia acetabulum (Ulvophyceae, Dasycladales), life history. a Young zygote with diploid zygote nucleus; b older zygote with growing diploid zygote nucleus; c young erect plant with diploid zygote nucleus in rhizoidal portion of plant; d,e development of whorls of sterile hairs on plant with diploid giant nucleus; $f$ after meiosis of the giant nucleus the haploid daughter nuclei have formed, by successive mitoses, numerous tiny haploid nuclei which are transported to other parts of the plant by protoplasmic streaming; an umbrella-like whorl of gametangia has been formed on the tip of the stalk; $g$ the umbrella-like whorl of gametangia, each gametangium filled with numerous gametangial cysts; $h, h^{1}$ two cysts, each with one haploid nucleus; $j, j^{1}$ the cysts have produced biflagellate isogametes of opposite sex; l,m isogamy. GC = gametangial cyst; $\mathrm{GN} 2 \mathrm{n}=$ giant nucleus, diploid; $\mathrm{MHN}(\mathrm{n})=$ migrating haploid $(\mathrm{n})$ nuclei; $\mathrm{R}$ ! = reduction division; $\mathrm{WH}=$ whorl of hairs; WHS = whorl of hairscars; $\mathrm{U}=$ umbrella-like whorl of gametangia

1969, 1972b, 1980) (Fig. 16), Halimeda (Meinesz, 1972a, 1980), Caulerpa (Price, 1972; Enomoto \& Ohba, 1987), Bryopsis (Rietema, 1969, 1970, 1971, 1975; Neumann, 1969a). Karyological evidence is, however, lacking or unconvincing.

In the life history of Derbesia (Fig. 17) a spherical gametophyte stage alternates with a branched sporophyte stage. This life history was discovered 50 years ago by Dr. Kornmann (Kornmann, 1938). Meiosis was later indubitably demonstrated in the pearshaped sporangia of Derbesia (Neumann, 1969b; Rietema, 1972, 1975). Eckhardt et al. (1986; see also Eckhardt \& Schnetter, 1984; Schnetter et al., 1985) discovered that gametic fusion results in the growth of an haploid, dikaryotic sporophyte. Only in the tips of the pear-shaped meiosporangia do the nuclei fuse to form the large zygote nuclei. These zygote nuclei are apparently the only diploid nuclei in this life history. 


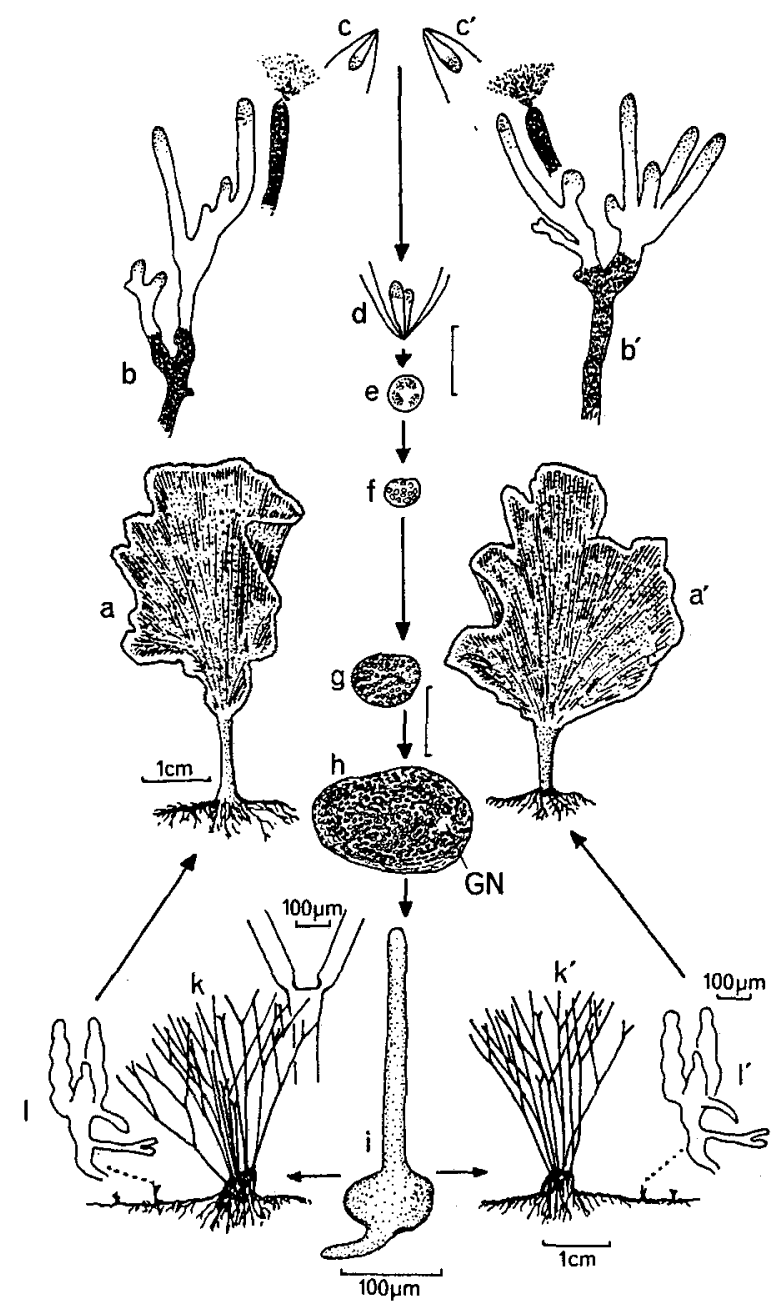

Fig. 16. Udotea petiolata (Ulvophyceae, Bryopsidales), life history, $a, a^{1}$ Gametophyte; $b, b^{1}$ exit papillae of gametes along margins of holocarpic thallus; $c$ biflagellate male gamete; $c^{1}$ biflagellate female gamete; d anisogamy; e young zygote; f-h development of young zygote into full-grown spherical zygote (protosphere) with giant nucleus (GN); i after nuclear division the protosphere buds off an erect and a rampant siphon; $k, k^{1}$ development of dichotomously branching plants from the protosphere; $1,1^{1}$ initiation of fan-like fronds from special swollen primordia on stolons grown from protosphere (Based on Meinesz, 1980)

Haplodiplontic life histories seem to have evolved at least four times in the Chlorophyta; namely in the orders Ulvales and Cladophorales of the class Ulvophyceae (see Tanner, 1981; van den Hoek, 1981), presumably in the class Trentepohliophyceae (Chapman, 1984) and in the mosses and vascular plants (the charophycean lineage). 


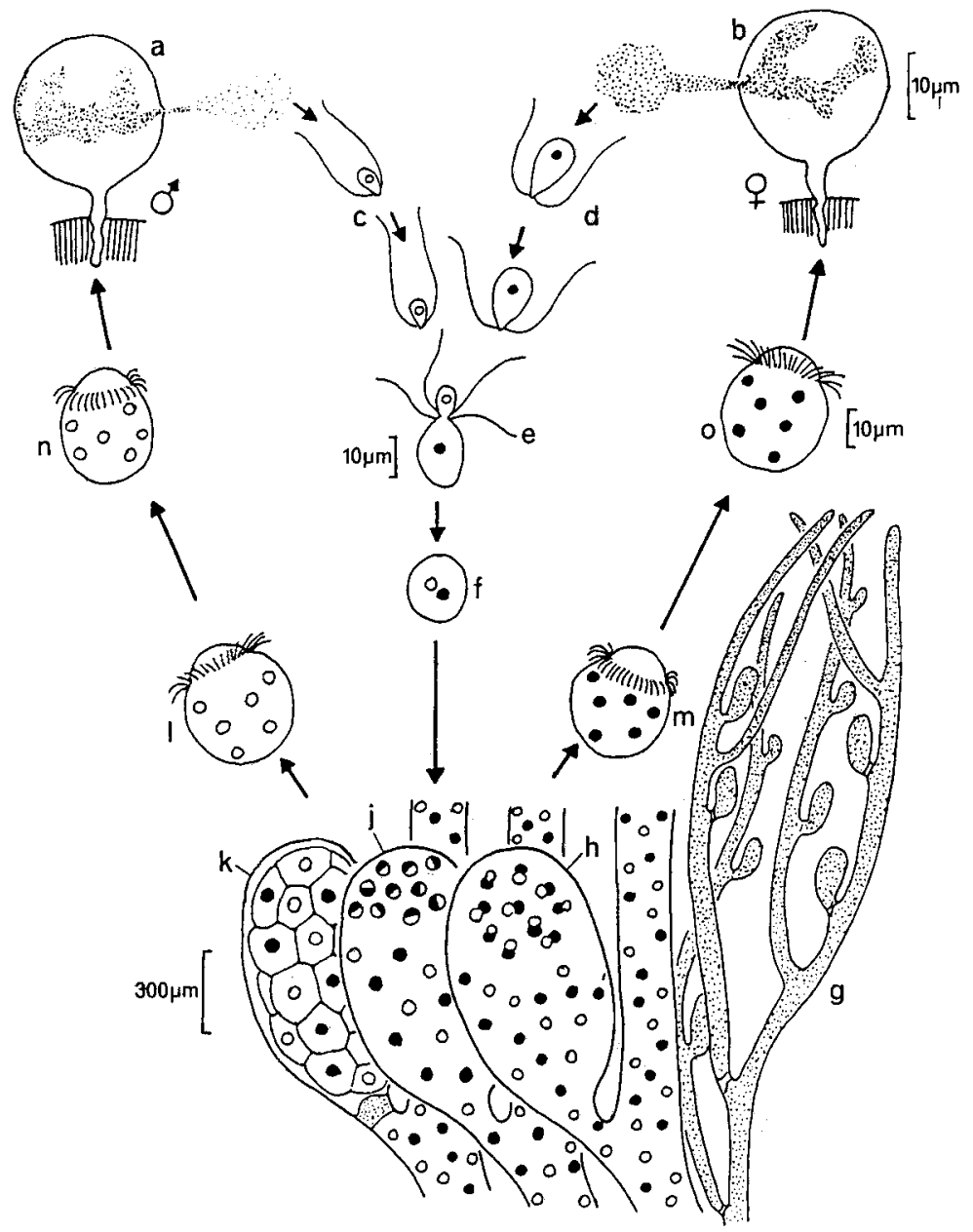

Fig. 17. Derbesia marina (Ulvophyceae, Bryopsidales), life history. a Male gametophyte; b female gametophyte ("Halicystis stage"); c male gametes; $d$ female gametes; e anisogamy; f heterokaryotic (dikaryotic), haploid product of cytogamy; $g$ sporophyte ("Derbesia stage"); $h$ heterokaryotic sporophyte, detail with young sporangium, karyogamy between male (open) and female (filled) nuclei in apical portion of young sporangium; $j$ heterokaryotic, haploid sporophyte, detail with young sporangium, diploid zygote nuclei in apical portion of sporangium just before meiosis; $k$ heterokaryotic sporophyte, detail with full-grown sporangium after meiosis, note that half of the young meiospores contain male (open) nuclei, the other half female (filled) nuclei, note also the basal plug separating the sporangium from the vegetative thallus; $1, n$ stephanokontan meiospores with male (open) nuclei; m,o stephanokontan meiospores with female (filled) nuclei (Based on Kornmann, 1938; Eckhardt et al., 1986)

\section{Organizational level and thallus architecture}

Each of the three classes Ulvophyceae, Chlorophyceae and Charophyceae contains one order with widely divergent organizational levels, namely the Codiolales, Cylindrocapsales, and Klebsormidiales, respectively (Table 2). 
Most orders have only one organizational level, and this often exhibits features that are unique to the order (or sometimes class). Examples are the Dasycladales, Oedogoniales, Zygnematophyceae, Charales. These are traditionally uncontroversial groups.

\section{Habitat type}

Habitat type is here considered characteristic at the class level. Some lineages have evolved in the sea, others in freshwater, and still others on the land (probably from freshwater ancestors). There are a few exceptions in several groups. For instance, within the Ulvophyceae several species of Ulothrix (Codiolales) and Cladophora (Cladophorales) are restricted to freshwater. The reverse (occurrence of species of freshwater classes in the sea) is quite rare, although penetration into brackish water does occur (e.g. by Charales, Zygnematophyceae).

\section{IMPLICATIONS OF THE NEW SYSTEM AND ITS UNDERLYING HYPOTHESES}

Figure 18 summarizes the new system and the underlying hypotheses. Note that the phylogenetic tree no longer reflects the idea of a step-wise evolutionary progression of organizational levels in which the flagellate level represents the most primitive lineage, the coccoid and sarcinoid levels lineages of intermediate derivation, and the filamentous, siphonocladous and siphonous levels the most derived lineages (Fig. 1).

Only the traditional hypothesis that the flagellate organizational level is primitive, has been retained in the new phylogenetic scenario. In this scenario, the various organizational levels have been realized over and over again within the main lineages (classes). For instance, unbranched Ulothrix-like filaments occur in the Ulvophyceae (Ulothrix, order Codiolales), the Chlorophyceae (Uronema, order Chaetophorales) and the Charophyceae (Klebsormidium, order Klebsormidiales). The phylogenetic heterogeneity of Ulothrix-like filaments has recently been confirmed by Schlösser's (1987) discovery that Uronema-autolysins are also effective in other filamentous genera of the order Chaetophorales, class Chlorophyceae (Stigeoclonium, Draparnaldia, Chaetophora), but not in Ulothrix (Ulvophyceae) and Klebsormidium (Charophyceae). Autolysins bring about the dissolution of filaments into cells, or the opening of exit pores through enzymatic degradation of cell wall polysaccharides.

Coccoid representatives are known in the Chlamydophyceae (e.g. Chlorococcum), Ulvophyceae (Chlorocystis, order Codiolales), the Chlorophyceae (e.g. Golenkinia, order Cylindrocapsales) and the Charophyceae (e.g. Raphidonema, order Klebsormidiales). Sarcinoid genera occur in the Chlorophyceae (e.g. Chlorosarcinopsis, order Cylindrocapsales), in the putative class Pleurastrophyceae (Friedmannia, cf. Melkonian \& Berns, 1983) and in the Charophyeae (Chlorokybus, order Klebsormidiales).

Each of the three classes Ulvophyceae, Chlorophyceae and Charophyceae contains one order with considerable diversity in the organizational levels, namely the orders Codiolales, Cylindrocapsales, and Klebsormidiales, respectively. Each of these three orders can possibly be interpreted as being relatively primitive within its own class, as it contains some representatives which have retained a primitive, ancestral coccoid or sarcinoid organization. Even these within-class coccoid and sarcinoid forms are probably 


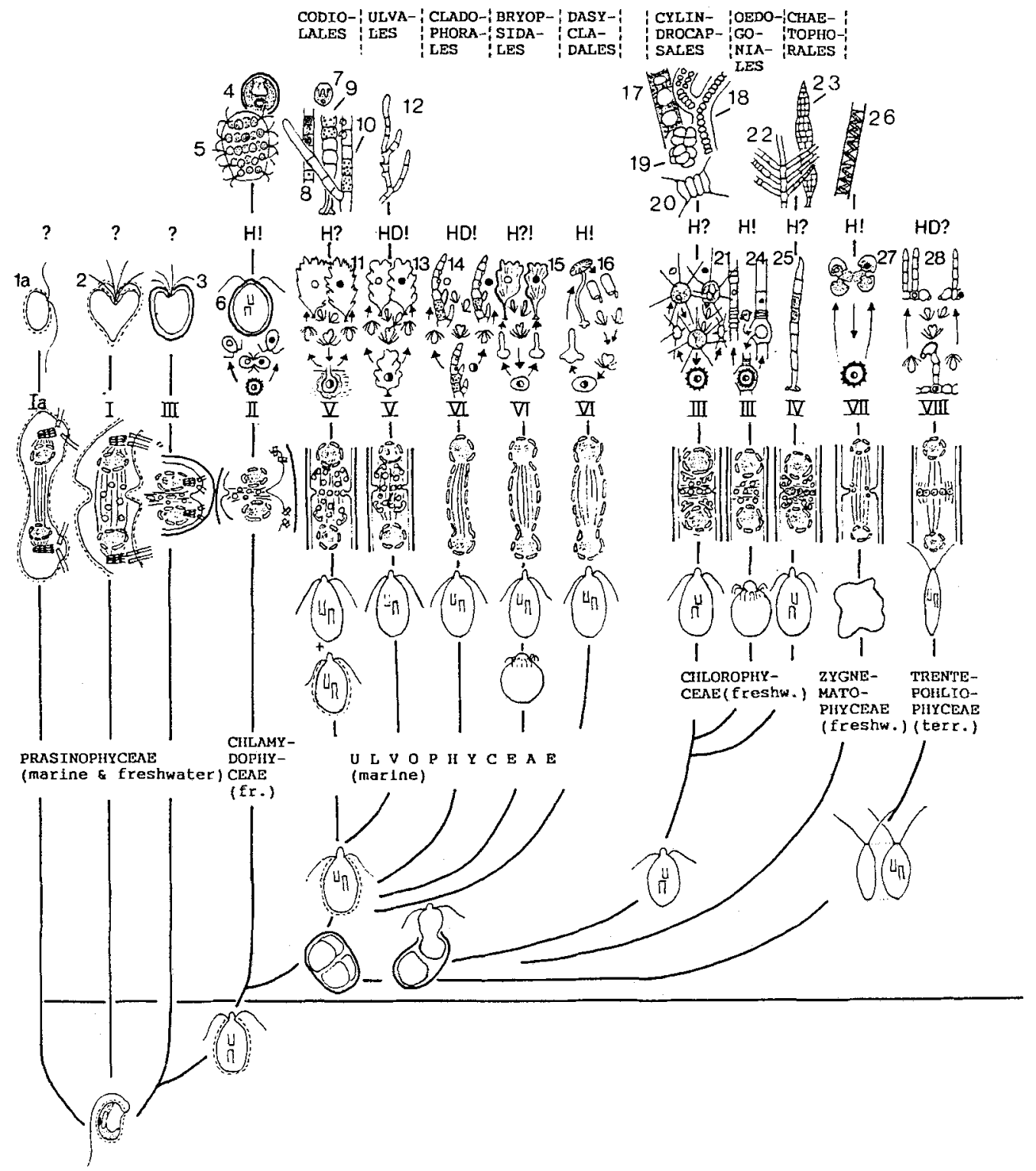

Fig. 18. Phylogeny and subdivision of Chlorophyta in the present treatise. 1 Nephroselmis (the scaly covering is indicated); 2 Pyramimonas (note the scaly covering); 3 Tetraselmis (note the theca around the cell); 4 Chlorococcum; 5 Eudorina; 6 Chlamydomonas (note the cell wall); 7 Chlorocystis; 8 Ulothrix; 9 Urospora; 10 Acrosiphonia; 11 Monostroma; 12 Acrochaete; 13 Ulva; 14 Cladophora; 15 Udotea; 16 Acetabularia; 17 Sphaeroplea; 18 Radiofilum; 19 Chlorosarcinopsis; 20 Scenedesmus; 21 Golenkinia; 22 Stigeoclonium; 23 Schizomeris; 24 Oedogonium; 25 Uronema; 26 Spirogyra; 27 Cosmarium; 28 Trentepohlia; 29, 30 Klebsormidium; 31 Chlorokybus; 32 Raphidonema; 33 Coleochaete; 34 Chara. Life history types: ? unknown, H! haplontic, karyological evidence available; $\mathrm{H}$ ? presumably haplontic, no karyological evidence; HD! haplodidplontic, karyological evidence available; HD? presumably haplodiplontic, no karyological evidence available. Type of mitosiscytokinesis (see also Figs 9-12). I. Open mitosis with a persistent telophase spindle, cytokinesis by a cleavage furrow. Ia. Closed mitosis with a persistent telophase spindle, cytokinesis by a cleavage furrow. II. Closed mitosis with a non-persistent telophase spindle, cytokinesis by a cleavage furrow in a phycoplast. III. Closed mitosis with a non-persistent telophase spindle, cytokinesis by a cell plate 


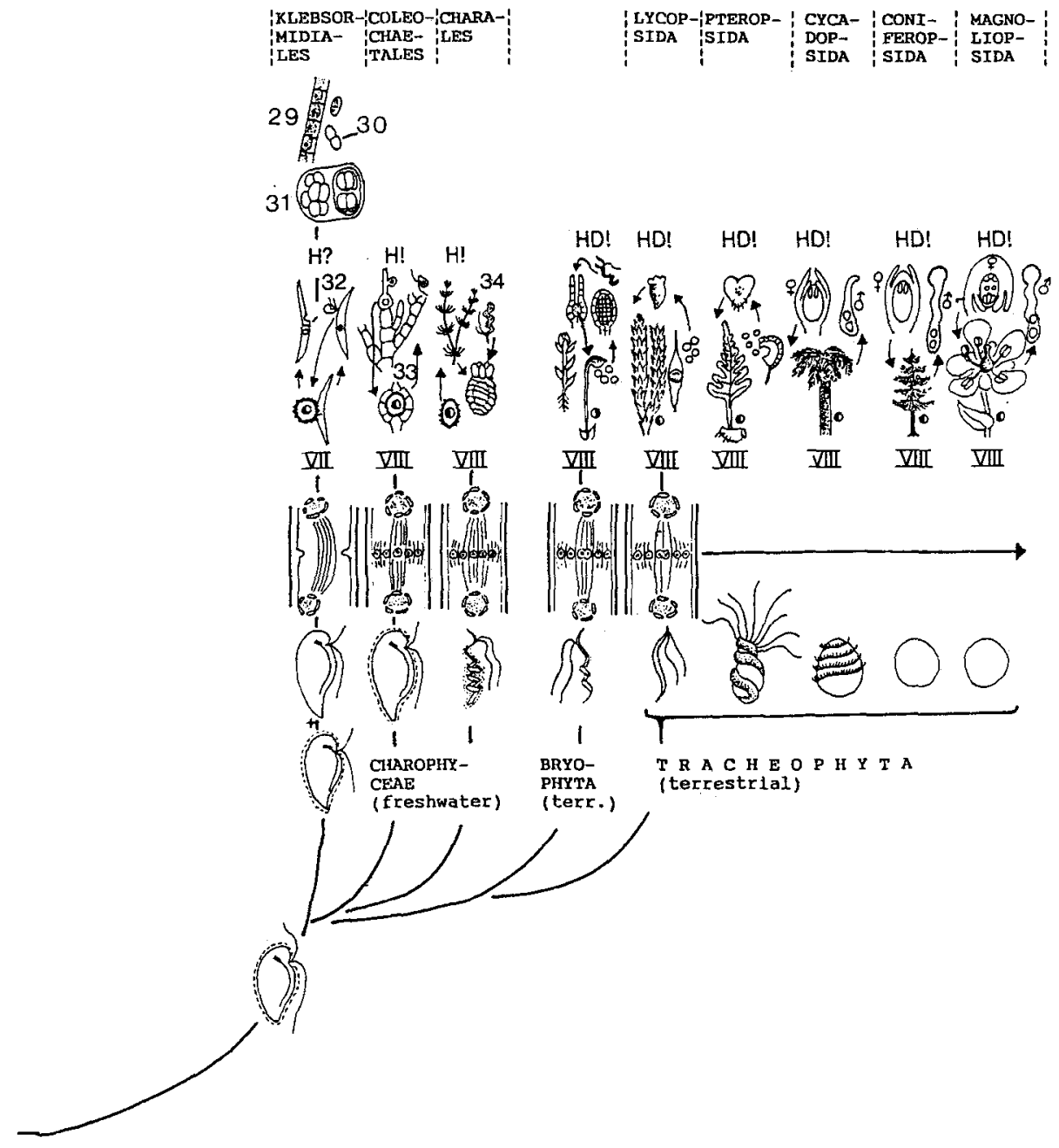

of smooth ER vesicles in a phycoplast. IV. Closed mitosis with a non-persistent telophase spindle, cytokinesis by a cell plate of Golgi-derived vesicles in a phycoplast. V. Closed mitosis with a persistent telophase spindle; cytokinesis by a cleavage furrow to which Golgi-derived vesicles are added. VI. Closed mitosis with a prominent persistent telophase spindle giving the telophse nucleus a typical dumbbell shape, cytokinesis does not immediately follow mitosis. VII. Open mitosis with a prominent persistent telophase spindle, cytokinesis by a cleavage furrow. VIII. Open mitosis with a prominent persistent telophase spindle, cytokinesis by a cell plate of Golgi-derived vesicles in a phragmoplast. The pictures of the cruciate zoids in the Ulvophyceae and Trentepohliophyceae contain a top view of the 11 o'clock/5 o'clock configuration of the basal bodies; the pictures of the zoids in the Chlorophyceae and Chlamydophyceae contain a top view of the $1 \mathrm{o}^{\prime} \mathrm{clock} / 7 \mathrm{o}$ 'clock configuration of the basal bodies. Note the scaly coverings of zoids in the Prasinophyceae, Ulvophyceae (Codiolales), and Charophyceae. Note also the hypothetical uniflagellate scaly prasinophycean ancestor (bottom left). The present day species Mantoniella squamata is the model of this ancestor (Manton \& Parke, 1960; Ettl, 1983) 
paraphyletic as they vary in cell structure, more particularly in chloroplast structure (Groover \& Bold, 1969; Komárek \& Fott, 1983).

The coccoid "genus" Chlorella and even phenotypic "species" appeared to be genetically highly heterogeneous (Kessler, 1984; Huss et al., 1986, 1987a, 1987b) and this supports the above idea that coccoid forms, even within one order, may be paraphyletic, or even convergent if coccoid forms were the result of reduction from multicellular forms. The order Ulvales (class Ulvophyceae) contains branched filamentous and thallose architectures.

The remaining orders within the above three classes have each virtually one organizational level. Most of these remaining orders have many unique features which define them as internally consistent (e.g. Cladophorales, Dasycladales, Oedogoniales, Charales). This latter remark is also valid for the classes Zygnematophyceae and Trentepohliophyceae.

Basic to the new system is the hypothesis that each main evolutionary lineage (as a class) is defined by its own type of flagellate cell. Thus the Ulvophyceae have cruciate reproductive zoids with 11 o'clock/5 o'clock positions of the basal bodies; the Chlorophyceae have cruciate reproductive zoids with $10^{\prime}$ clock/7 o'clock positions of the basal bodies; and the Charophyceae have unilateral reproductive zoids with a MLS. Note that the bryophytes and tracheophytes in this scenario belong to the Charophyceae as they have unilateral zoids and a charophycean mitosis-cytokinesis: To accommodate the enormous diversity in the land plants one needs at least classes (e.g. Coniferopsida) or even divisions (e.g. Coniferophyta) for their main groups. We have here refrained from an attempt to devise a unified taxonomic hierarchy for the green algae and the mosses and vascular plants. This would be perhaps desirable from a theoretical, but not from a practical point of view.

Zoids are thought to be the depositories of evolutionarily old characters, because flagellate cells with their eukaryotan " $9+2$ " flagella occur in widely different organisms. The implication of this idea is that free living flagellates of one major group such as the Chlorophyta are more primitive (i.e. have preserved more ancestral characters) than their non-flagellate representatives and that all non-flagellate representatives have ultimately evolved from flagellate ancestors. Flagellate forms have often been ranged in one main group (e.g. the Volvocales in the Chlorophyta) which was considered ancestral to all other groups.

With regard to the flagellate chlorophytes, however, the idea gradually gained support that there is, apart from the Volvocales, at least one other main lineage of chlorophytan flagellates. This lineage is now generally designated as the class Prasinophyceae which is, as we have seen, characterized by its highly elaborate organic body and flagellar scales (cf. Norris, 1980). On the basis of various arguments the Prasinophyceae are generally regarded as the most primitive group of the Chlorophyta (see Norris, 1980). One argument is that the architectural diversity of this group designates it as a laboratory for the evolution of the different green flagellate cell forms. This diversity of flagellate cell architecture in the Prasinophyceae is schematically illustrated in Figure 18. Note that the hypothetical ancestral prasinophycean (for which the present-day Mantoniella serves as an example) is scaly and uniflagellate. The idea is that biflagellate, quadriflagellate and even octoflagellate Prasinophyceae evolved eventually from a uniflagellate ancestor by a shift in the timing of cytokinesis relative to the semi-conservative basal body (and hence 
flagellar) replication (cf. Norris, 1980; Melkonian et al., 1987; Melkonian, pers. comm.). A recent argument for the primitiveness of the Prasinophyceae is that the main character of this class, the possession of body scales; is shared with the reproductive zoids in widely divergent chlorophytes (Fig. 18). The possession of this ancestral trait is thought to have been conserved in several very remote multicellular chlorophytes and to point to an ancient divergence of these groups. In a comparable way, the possession of the $9+2$ flagellum by unrelated eukaryotes as mammals, chytrids and chlorophytes is thought to point to an exceedingly ancient evolutionary divergence in the primaeval eukaryotes.

This comparison also indicates the problematic nature of the characterization of the Prasinophyceae by an admittedly primitive, ancestral trait which can be identified as such because of its occurrence in other widely different classes. Actually, even though an ancestral trait such as the possession of organic body and flagellar scales is conserved in only a portion of the lineages contained in the Chlorophyta, it can only be used to characterize the Chlorophyta as a whole. In a similar way, the possession of " $9+2$ " flagella can only characterize (almost) the whole realm of the eukaryotes, although some lineages have secondarily lost these flagella (in the chlorophytes, a. o., the Zygnematophyceae and most vascular plants, see Fig. 18).

The above reflections apparently undermine the concept of the class Prasinophyceae as proposed at the beginning of this paper. For further, different reasons, the phylogenetic scenario of the chlorophytes in Figure 18 is incompatible with the concept of the Prasinophyceae.

The cruciate reproductive zoids of the Ulvophyceae plus Chlorophyceae are thought to have evolved from a free living scaly prasinophycean ancestor (Hoops et al., 1982; Stewart \& Mattox, 1978). Tetraselmis has been suggested as the nearest living relative of this ancestor (Moestrup, 1982; Sluiman et al., 1980a Stewart \& Mattox, 1975).

The present scenario specifies this idea as follows. In the ancient epoch of divergence and radiation in the early flagellate chlorophytes, one Chlamydomonas-like chlorophyte possibly emerged which still had a scaly covering and $12 o^{\prime}$ clock $/ 6$ o'clock positions of the basal bodies. This was the common ancestor of the Chlamydophyceae, and of the multicellular and siphonous green algae with cruciate reproductive zoids. In this latter assemblage, an early divergence took place between the multicellular greens whose cruciate reproductive zoids evolved 11 o'clock/5 o'clock positions of the basal bodies (the Ulvophyceae); and the multicellular greens with reproductive cells having 1 o'clock/7 $o^{\prime}$ clock positions of the basal bodies. This latter configuration does not differ much from the hypothetical $12 o^{\prime}$ clock/ 6 o'clock ancestral configuration.

The unilateral reproductive zoid of the Charophyceae, in its turn, might be thought to have evolved from a free-living unilateral prasinophycean ancestor. Nephroselmis has been suggested as the nearest living relative of this ancestor (Moestrup \& Ettl, 1979). Nephroselmis does superficially resemble the unilateral charophycean zoid, with which it shares a broad lateral microtubular root, the possession of a MLS-like structure, and a scaly covering (Fig. 8). The implication of the above two hypotheses is that Tetraselmis would be more closely related to the Chlamydophyceae, Chlorophyceae and the Ulvophyceae than to the remaining Prasinophyceae, and that Nephroselmis would be more closely related to the Charophyceae than to the remaining Prasinophyceae.

A scenario in which the cruciate reproductive zoid is derived from a Tetraselmis-like ancestor, and the unilateral reproductive zoid from a Nephroselmis-like ancestor, also 
implies that these two free living chlorophytan flagellates have survived almost unchanged since the early radiation of non-flagellate chlorophytes. This accords with the basic hypothesis that flagellate cells are phenotypically conservative. A consequence of this basic hypothesis is therefore that the Prasinophyceae are a conglomerate of very old lineages (classes) which have retained the ancestral trait of the organic body and flagellar scales. The high diversity in flagellate cell architecture (e.g. in Ettl, 1983, Table I, p. 97), in flagellar root systems (Melkonian, 1984; Moestrup, 1982, 1987; Norris, 1980), and types of mitosiscytokinesis (Barlow \& Cattolico, 1981; Mattox \& Stewart, 1977; Norris, 1980; Pearson \& Norris, 1975; Stewart et al., 1974; Woods \& Triemer, 1981) which are encountered in the Prasinophyceae underline the heterogeneity of the "class" (see Fig. 18).

It would perhaps now be theoretically preferable to place each Prasinophycean genus in its own class, but this would result in an unwieldy system which would in practice hamper the discussions. We would also hesitate to place Tetraselmis and Nephroselmis in other classes than the Prasinophyceae, as the homologies justifying such decisions are of a highly tentative nature. For instance, the MLS-like structure in Nephroselmis differs in details from that in the Charophyceae (Moestrup \& Ettl, 1979) and there are wide differences between Tetraselmis and Chlamydomonas.

Only limited ultrastructural information is available about the genera ranged here under the Chlamydophyceae (Ettl \& Moestrup, 1980). This information suggests that the class is characterized by a cruciate $1 \mathrm{o}^{\prime}$ clock/7 o'clock configuration of the flagellar apparatus and by a closed mitosis with a non-persistent telophase spindle and by a glycoprotein lattice in the cell wall (Table 2 ; Fig. 9, bottom); cytokinesis is by a cleavage furrow in a phycoplast.

The class harbours architecturally very diverse (especially with regard to chloroplast structure) cruciate flagellates whose ultrastructure is largely unknown (see Ettl, 1983, Table III on p. 194). This high diversity suggests that the Chlamydophyceae also consist of a bundle of old lineages (classes), as flagellates are hypothesized to be phenotypically conservative and therefore to change slowly.

In most recently proposed phylogenies (Deason, 1984; Hoops et al., 1982; Mattox \& Stewart, 1984; Melkonian, 1982; O'Kelly \& Floyd, 1984; Sluiman, 1985b; Sluiman et al., 1980a) the Chlamydophyceae (proposed by Ettl, 1981, and here adopted in a slightly different sense) are included in the Chlorophyceae because of the similarity in flagellate cell architecture. This is, however, not consistent with the basic hypothesis that flagellates are primitive with regard to multicellular and siphonous algae. In these phylogenies, the ulvophycean type of cruciate zoid (with an $11 \mathrm{o}^{\prime}$ clock/5 o'clock configuration of the basal bodies; Figs 6,7 ) is generally considered more primitive than the chlorophycean type of cruciate zoid (with a 1 o'clock/7 o'clock configuration, Figs 5,6 ). One important reason is that many ulvophycean zoids are covered by organic body scales which resemble the underlayer body scales of the Prasinophyceae (Hoops et al., 1982; Mattox \& Stewart, 1984; O'Kelly \& Floyd, 1983; Sluiman, 1985b). The chlorophycean type of zoid is thought to have evolved from the ulvophycean zoid type by a gradual clockwise shift of the basal bodies (cf. Fig. 6) and by the loss of organic body scales. One illogical consequence of this reasoning is that a group of free-living flagellates-Chlamydomonas and its allies - is considered as derived from a group of multicellular and siphonous green algae. This clearly contradicts the basic hypothesis that free-living flagellate green algae are primitive with regard to the non-flagellate greens. 
The flagellate "classes" Prasinophyceae and Chlamydophyceae are probably bundles of ancient, conservative lineages each of which could be theoretically considered as a separate class. A comparable reasoning could.be applied to the putatively primitive orders Codiolales (class Ulvophyceae), Cylindrocapsales (class Chlorophyceae), and Klebsormidiales (class Charophyceae). These orders contain, by definition, relatively conservative genera and could hence be considered as bundles of evolutionarily old lineages (e.g. orders).

We have argued above that the primitive, ancestral, phenotypically conservative chlorophytan lineages within Prasinophyceae and Chlamydophyceae in our phylogenetic hypothesis are very ancient lineages.

In contrast, the most derived phenotypically highly differentiated chlorophytan lineages, for instance those in flowering plants, should be, according to our hypotheses, very young and the product of rapid phenotypic change. Lineages of intermediate derivation, for instance the classes of the Ulvophyceae, Chlorophyceae and Charophyceae should have an intermediate age. Within the most ancient and conservative lineages, extant genera and species can also be expected to be phenotypically conservative and hence to be "old". Within the youngest phenotypically most derived lineages, on the other hand, the genera and species can be also expected to be phenotypically derived and hence to be "young".

Our phylogenetic scenario therefore predicts that the extant phenotypically defined genera and species in ancestral conservative lineages have, on average, diverged relatively long ago because phenotypic change is here a slow process; and that phenotypically defined genera and species in derived lineages have diverged, on average, much more recently because phenotypic change is here a rapid process.

This prediction can be tested by two approaches; first by inspecting the fossil record; second by estimating relative divergence times on the basis of comparisons between macromolecules bearing genetic information.

\section{Fossil evidence}

Figure 19 summarizes the available fossil evidence about the geologic occurrence of chlorophytan taxa. Uninterrupted lines indicate more or less solid evidence, interrupted lines more or less speculative identifications. Actually, only for the geologic occurrence of the Prasinophyceae, the Bryopsidales, the Dasycladales and the Charales is abundant and reliable evidence available. The occurrence of vascular plants is well documented from ca 400 million years ago onwards, and of flowering plants from about 115 million years onwards (not indicated in Fig. 19).

The fossil evidence suggests indeed that the Prasinophyceae are very ancient (at least $600 \mathrm{Ma}$, perhaps $1400 \mathrm{Ma}$ ). The oldest reliable records of the Ulvophyceae and Charophyceae are about $400-500 \mathrm{Ma}$, and these are fossils of the most derived orders within the two classes (the Dasycladales in the Ulvophyceae, the Charales in the Charophyceae). The oldest vascular plants are ca. $400 \mathrm{Ma}$. These data suggest that the radiation of the chlorophytan classes took place far earlier than $500 \mathrm{Ma}$ ago.

If we consider the geologic occurrence of still extant genera, the differences become more striking. The prasinophycean genera Pterosperma and Pachysphaera would be at 


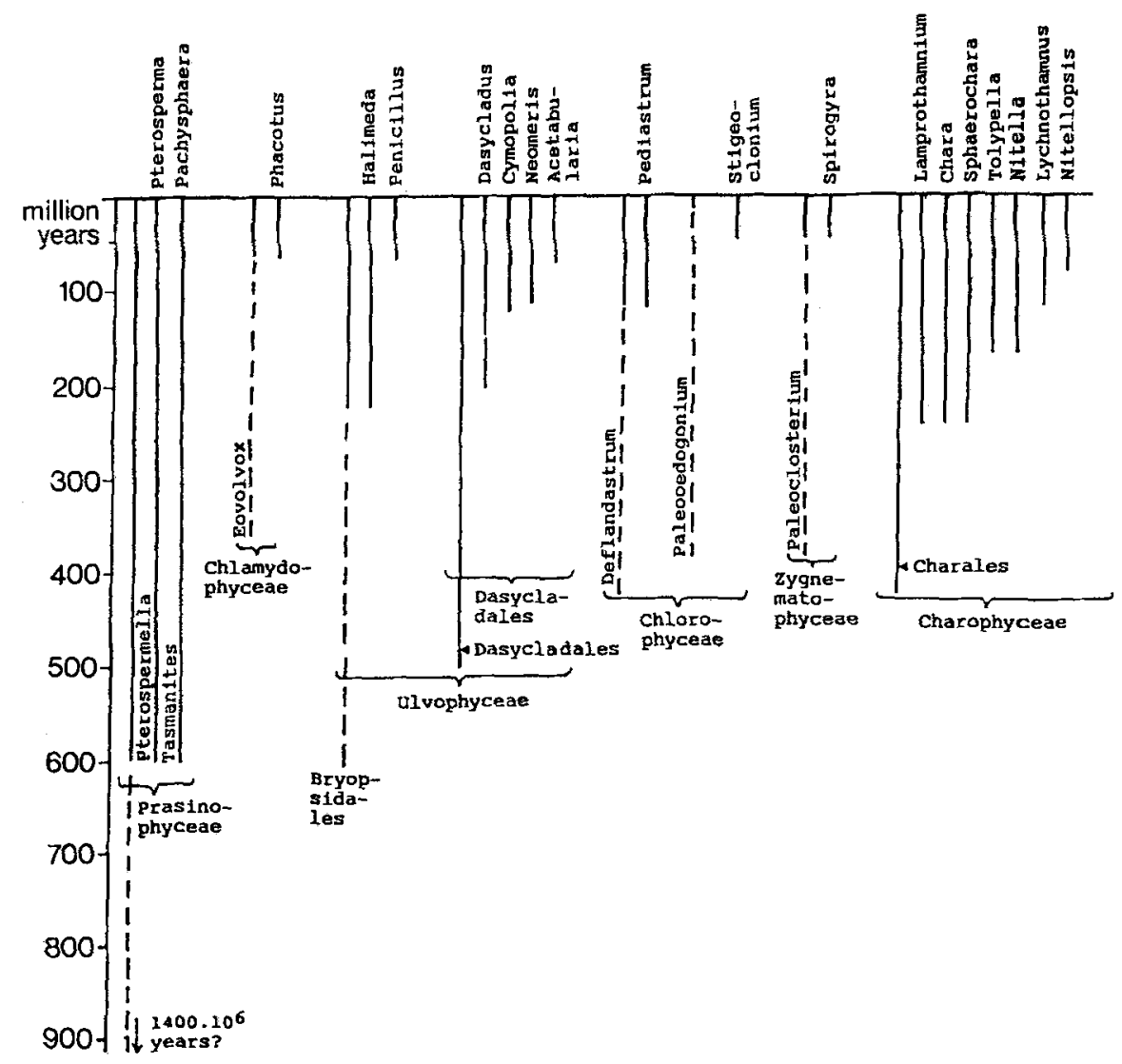

Fig. 19. Geologic occurrence of chlorophytan classes and orders, and of a number of extant genera (Based on Bassoulet et al., 1978; Colbath, 1983; Elliott, 1981; Hillis-Colinvaux, 1980; Parke et al., 1978; Souliè-Märsche, 1979; Tappan, 1980)

least $600 \mathrm{Ma}$ old if the fossil genera Pterospermella and Tasmanites do indeed belong to the two recent genera (Boalch \& Parke, 1970; Parke et al., 1978).

Some extant ulvophycean genera would have minimum-ages of about 230-80 Ma; and some extant charophycean genera (in the Charales) of about 250-80 Ma (Fig, 19). Some extant conifer genera are at least $150-50 \mathrm{Ma}$ old; and extant flowering plant genera about 60-5 Ma (Meyen, 1987; Müller, 1981; Thomas \& Spicer, 1986).

The much smaller phenotypic change within the primitive chlorophytes than in the derived chlorophytan groups is also suggested by the low green algal diversity (7000-8000 species) as compared to the high diversity in the vascular plants (ca 250,000 species, of which ca 200,000 are flowering plants). 


\section{Macromolecular evidence}

After two related evolutionary lineages have diverged, their initially similar genomes will automatically and inexorably diverge with time even when these lineages remain morphologically highly similar (Ayala, 1986; Nei, 1987; Thorpe, 1982). By comparing the genetic codes as stored in nuclear DNA, chloroplast DNA, ribosomal RNA, proteins, it is possible to quantify the measure of genetic divergence between lineages of more or less related organisms and thus to indicate which lineages are genetically more closely related (i.e. diverged more recently) and which are more distantly related (i.e. diverged relatively long ago). These methods do of course not permit the reconstruction of extinct ancestors.

By comparing with these methods genomes of representative species of principal hypothetical lineages one can attain estimates of relative divergence times among lineages and thus test the validity of the hypothetical phylogeny. This approach has been applied by Hori and his associates (Hori et al., 1985; Hori \& Osawa, 1987). They have studied the phylogenetic relationships among a wide spectrum of extant organisms using 5S ribosomal RNA sequences. This is one of the molecules suited to the study of evolutionary relationships among widely separate organisms because of its universal occurrence and the low substitution rates of its nucleotides. As a part of these studies, the evolutionary relationships among the green plants (Chlorophyta, mosses, liverworts, and vascular plants) were determined. The results are summarized in Figure 20. Only a few green algae from divergent groups were included in this study.

One is actually amazed that various hypotheses underlying the phylogenetic tree of Figure 18 are supported by Hori's 5S rRNA-phylogenetic tree. The following hypotheses are confirmed:

(1) The mosses, liverworts and vascular plants evolved from green algal ancestors.

(2) The nearest green algal ancestor of the mosses, liverworts and vascular plants is in the lineage of the Charales. This supports the concept of the class Charophyceae.

(3) Chlamydomonas represents an ancient lineage in the green plants. This supports the idea that the free living green flagellates represent the most ancient lineages in the green algae.

(4) The remaining lineages of the green algae in this study emerged, in the course of evolution, after Chlamydomonas and before the Charales. Ulva and Cladophora on the one hand and the three coccoid green algae Scenedesmus A, Scenedesmus B and Chlorella on the other hand are distantly related; this supports the concepts of the classes Ulvophyceae and Chlorophyceae. Zygnematophyceae seem to be close to the Chlorophyceae.

(5) Chlamydomonas and the three coccoid green algae clearly do not belong to the same lineage (as proposed by Deason, 1984; Hoops et al., 1982; Mattox \& Stewart, 1984; Melkonian, 1982; O'Kelly \& Floyd, 1984; Sluiman, 1985b; Sluiman et al., 1980a).

Rather, the concepts of the separate classes Chlamydophyceae and Chlorophyceae, as proposed by Ettl (1981) and here adopted with slight modification, are confirmed by Hori's results.

One hypothesis pictured in Figure 18 is not confirmed by Hori's phylogenetic tree, namely the derivation of the Charophyceae from a separate (i.e. unilateral) green flagellate ancestor. Rather, the charophycean lineage seems to emerge at an early stage 


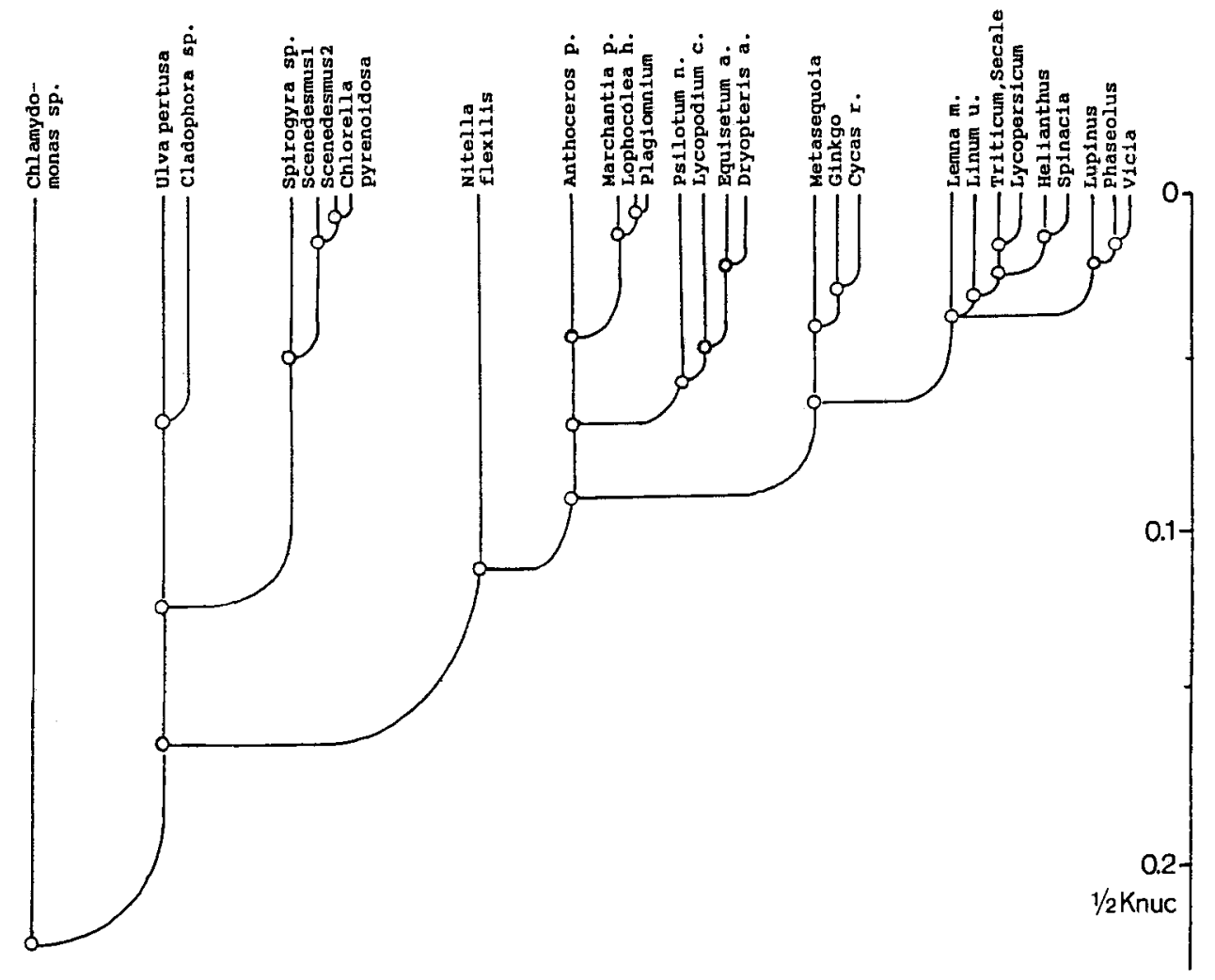

Fig. 20. Phylogenetic tree of 5S rRNA's from green plants (modified after Hori et al., 1985, and Hori \& Osawa, 1987). Knuc is the evolutionary distance between two sequences; $1 / 2 \mathrm{Knuc}$ between the point of divergence and each of the two sequences. Knuc estimates the number of base substitutions per nucleotide site that have occurred since the separation of the two sequences. Scenedesmus $1=S$. obliquus; $\mathrm{S} .2=S$. quadricauda; Anthoceros p. $=$ A. punctatus; Marchantia p. $=$ M. polymorpha, Lophocolea h. $=L$. heterophylla; Plagiomnium $=P$. trichomanes; Psilotum n. $=P$. nudum; Lycopodium c. $=$ L. clavatum; Equisetum a. $=$ E. arvense $;$ Dryopteris a. $=$ D. acuminata; Metasequoia $=M$. glyptostroboides; Ginkgo $=G$. biloba; Cycas r. $=$ C. revoluta; Lemna $\mathrm{m} .=$ L. minor; Linum u. $=L$. usitasissimum; Triticum $=T$. aestivum; Secale $=S$. cereale; Lycopersicum $=L$. esculentum; Helianthus $=H$. annuus; Spinacia $=S$. oleracea Lupinus $=$ L. luteus; Phaseolus $=P$. vulgaris; Vicia $=V$. faba

from a common lineage of multicellular green algae. This suggests that the evolutionary step from free living green flagellates to multicellular green algae took place only once. Another suggestion is that the unilateral reproductive zoids in the Charophyceae originated from cruciate reproductive zoids. The number, however, of species and the number of orders and classes represented is still extremely limited in this study so that the conclusions can only be preliminary. However, so far the studies of Hori and his collaborators are quite unique in phycology.

By comparing genomes of phenotypically close relatives one could, in principle, test the hypothesis that extant genera and species in presumptive ancient lineages are on 
average old (i.e. diverged long ago), as compared to genera and species in derived and young lineages. The literature contains scattered reports which might be relevant in this context. These reports are studies on chloroplast genome structure in green plants including green algae; DNA-DNA hybridization studies on the Cladophorales; and immunological studies in the latter group.

\section{Chloroplast genomes in green plants}

The organization of the chloroplast genomes of over 200 flowering plants, one gymnosperm, three ferns and two mosses, has been investigated. In contrast, the chloroplast genomes of only about ten green algae have been studied, among them four species of Chlamydomonas (Palmer, 1985).

With rare exceptions, the chloroplast genomes of land plants are extraordinarily conserved in size, gene content and gene order. The large majority of angiosperms and other land plants have chloroplast DNAs that vary between $120 \mathrm{~Kb}$ and $160 \mathrm{~Kb}$ in size. Most of this variation can be accounted for by changes in the size of the large rRNA encoding inverted repeat and this is caused by rare deletions and duplications. Inversions and other mutations that change the relative order of genes are extremely rare in the chloroplast DNAs of land plants.

Overall, the angiosperms and other land plants have the same conserved gene arrangement in the chloroplast genome. For instance, the arrangement of the liverwort Marchantia polymorpha is similar to that of most angiosperms, and this would imply that the land plant arrangement of the chloroplast genes exists at least since the evolutionary divergence of vascular plants and bryophytes ca $400 \mathrm{Ma}$ ago (Palmer, 1985; Palmer et al., 1987).

In contrast to this high similarity of chloroplast genomes in the land plants, the chloroplast DNAs of two distantly related Chlamydomonas species (C. eugametos and C. reinhardtii) are extremely divergent expecially with regard to gene order (Palmer, 1985; Lemieux et al., 1985). Lemieux and his co-workers suggest that $C$. eugametos and C. reinhardtii represent green algal lineages that diverged much earlier than the land plant lineages. This suggests a minimum age of $400-500 \mathrm{Ma}$ for the genus Chlamydomonas. Clearly this interpretation is in support of the basic hypothesis that the free living green algal flagellates represent phenotypically conserved, very slowly changing lineages.

Interestingly, phenotypically similar pairs of related, (partly) interfertile, species of Chlamydomonas (C. reinhardtii and $C$. smithii; $C$. eugametos and C. moewusii) share essentially the same arrangement of common sequences. There are, however, small differences in an order comparable to those among the land plants. Moore \& Coleman (1987) recently reported that geographically isolated populations in one and the same syngen (= interbreeding set of populations) of the colonial green flagellate Pandorina morum, differed in their chloroplast DNAs with an order comparable to that between genera and families in the flowering plants.

Non-interbreeding populations of the morphological species Pandorina morum, however, showed extensive differences in their chloroplast genomes. These results also support the idea that green algal flagellates are phenotypically highly conservative 
lineages. They suggest for the morphological species Pandorina morum a minimum age of 400-500 Ma. See Figure 19 which indicates the fossil occurrence of "Eovolvox" nearly $400 \mathrm{Ma}$ ago.

\section{Single-copy DNA-DNA hybridization}

Certain highly disjunct distributions of seaweed species may suggest their minimum ages. For instance, many tropical seaweed species occur in the Caribbean and the IndoW. Pacific, and this distribution pattern may be explained as being a Tethyan relict distribution (Elliott, 1981; Hillis-Colinvaux, 1980, 1986; van den Hoek, 1984b; Joosten \& van den Hoek, 1986). Of an originally continuous Tethyan area the western (Caribbean) and eastern (Indo-W. Pacific) portions became definitively separated by the Miocene (20 $\mathrm{Ma})$ uplift of the Middle East, but earlier temporary closures had also occurred. This suggests a minimum age of $20 \mathrm{Ma}$ for morphological species with this distribution pattern.

A considerable number of genera and species within the orders Cladophorales, Bryopsidales and Dasycladales of the class Ulvophyceae exhibit this tropical disjunct distribution. Fossil representatives of the extant Dasycladalean genera Dasycladus, Cymopolia, Neomeris and Acetabularia (see Fig. 19) had indeed a continuous distribution around the Tethys Ocean throughout the Cretaceous and the early Caenozoic (Elliott, 1981).

In our laboratory we try to estimate divergence times between infraspecific disjunct populations of morphological species using single-copy DNA-DNA hybridization. The difference in thermal stability between homoduplexes and heteroduplexes as determined from thermal elution profiles provides a measure of genotypic relationship. The temperatures are taken at which $50 \%$ of the hybrids are eluted. A difference (STM(e)) of $1{ }^{\circ} \mathrm{C}$ is estimated to equal on average $5.5 \mathrm{Ma}$ (Stam et al., 1988). Using this approach two disjunct Dictyosphaeria cavernosa isolates (Cladophorales) from Hawaii and the Virgin Islands were estimated to have diverged $55 \mathrm{Ma}$ ago and $D$. cavernosa and $D$. versluysii isolates ca $70 \mathrm{Ma}$ ago (Olsen et al., 1987). This indicates a high degree of morphological conservatism in Dictyosphaeria, with an unchanged $D$. cavernosa morphology from 70-50 Ma ago to present. In our laboratory, Bot obtained comparable results with highly disjunct isolates of morphological Cladophora species or species complexes (Bot et al., in prep.). Comparably low DNA homologies exist between strains of one and the same phenotypic Chlorella species, while different Chlorella species have a very low, or an undetectable level of DNA homology (Huss et al., 1986, 1987a, 1987b).

The above Dictyosphaeria isolates were also included in a broad study of phylogenetic relationships within the Cladophorales on the basis of immunological distance data (Olsen-Stojkovich et al., 1986; Olsen-Stojkovich, 1986). The relative divergence times of the three Dictyosphaeria isolates were the same as in the DNA-DNA hybridization study.

In the immunological study the relative divergence times (as immunological distances) were estimated between 43 isolates belonging to 26 species in 16 genera (Fig. 21). The results indicate a high degree of morphological conservatism within the Cladophorales as a whole, and also in its separate lineages representing the extant genera. Different Cladophora species emerged in distant portions of the phylogenetic tree and this confirms van den Hoek's idea that the genus Cladophora is paraphyletic (van den Hoek, 1984a). The different genera in the Cladophorales can be interpreted as various speciali- 
zations of the simple Cladophora architecture (probably of the C. pellucida-type; see van den Hoek, 1984b). The branches of the phylogenetic tree that changed relatively little in morphology retained, in slightly different forms, the simple ancestral Cladophora architecture. In a comparable way, sarcinoid and coccoid green algae form probably primitive paraphyletic bundles in the Cylindrocapsales (Chlorophydeae) and the Klebsormidiales (Charophyceae).

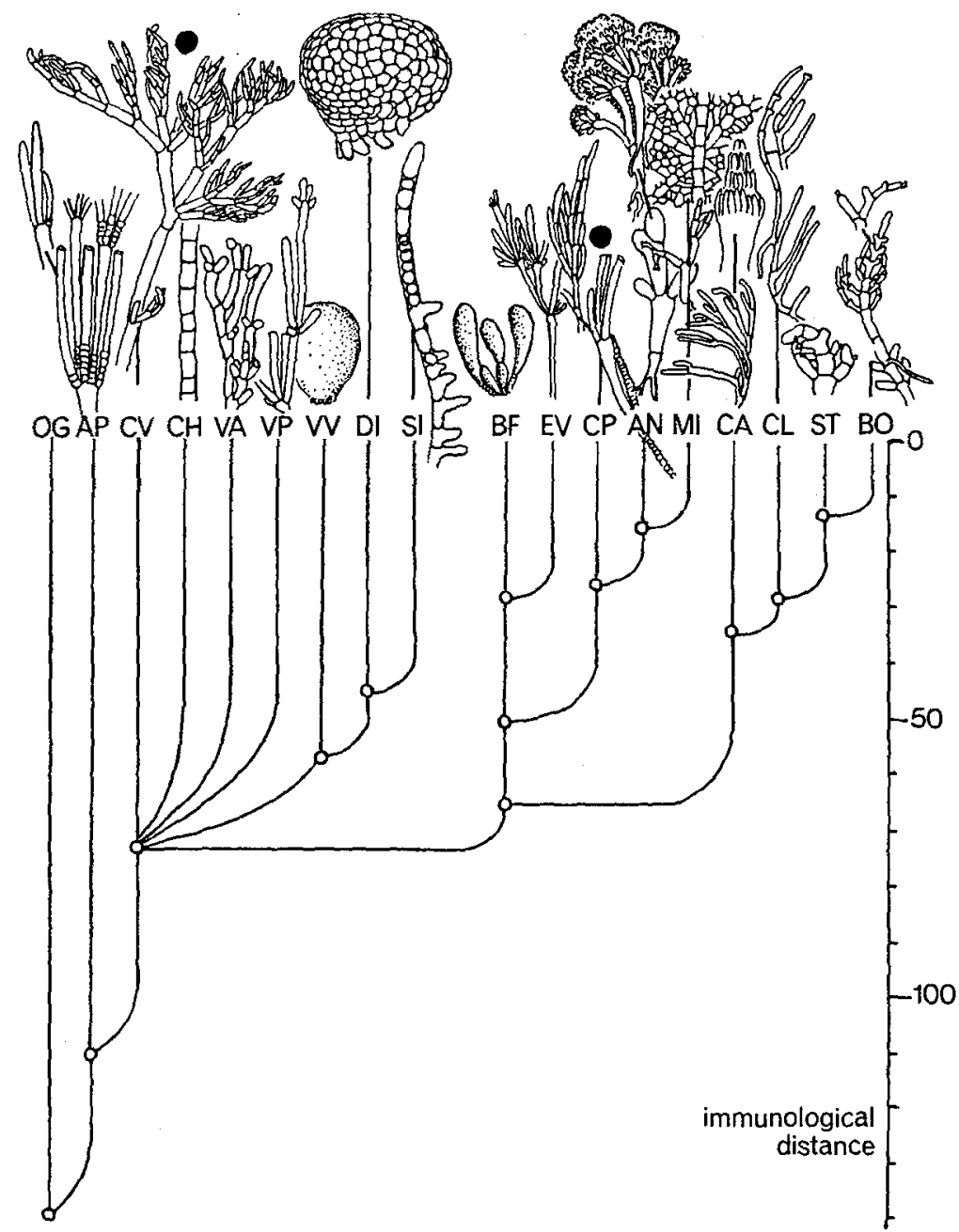

Fig. 21. Phylogenetic tree of genera in the Cladophorales, based on immunological distances per genus, as average of one or more species. $\mathrm{OG}=$ outgroup $=$ Acetabularia; $\mathrm{AP}=$ Apjohnia laetevirens; $\mathrm{CV}=$ Cladophora vagabunda $\mathrm{CH}=$ Chaetomorpha $4 \mathrm{spp}$; $\mathrm{VA}=$ Valonia $3 \mathrm{spp} . ; \mathrm{VP}=$ Valoniopsis pachynema; VV = Ventricaria ventricosa; $\mathrm{DI}=$ Dictyosphaeria $4 \mathrm{spp} ; \mathrm{SI}=$ Siphonocladus tropicus; $\mathrm{BF}=$ Boergesenia forbesi $; \mathrm{EV}=$ Ernodesmis verticillata $; \mathrm{CP}=$ Cladophora prolifera; $\mathrm{AN}=$ Anadyomene stellata; $\mathrm{MI}=$ Microdictyon setchellianum; $\mathrm{CA}=$ Chamaedoris peniculum $_{i} \mathrm{CL}=$ Cladophoropsis membranacea $; \mathrm{ST}=$ Struvea anastomosans; $\mathrm{BO}=$ Boodlea composita. Note that two species of Cladophora (dots) emerge at two different points of the tree, indicating the paraphyletic nature of this "genus" (Based on Olsen-Stojkovich, 1986) 
Table 3. Summary of estimated minimum age of extant genera and species in some chlorophytan classes. Between brackets: number of genera/species for which estimates are available. (f) = fossil evidence $_{i}(\mathrm{~m})=$ macromolecular evidence

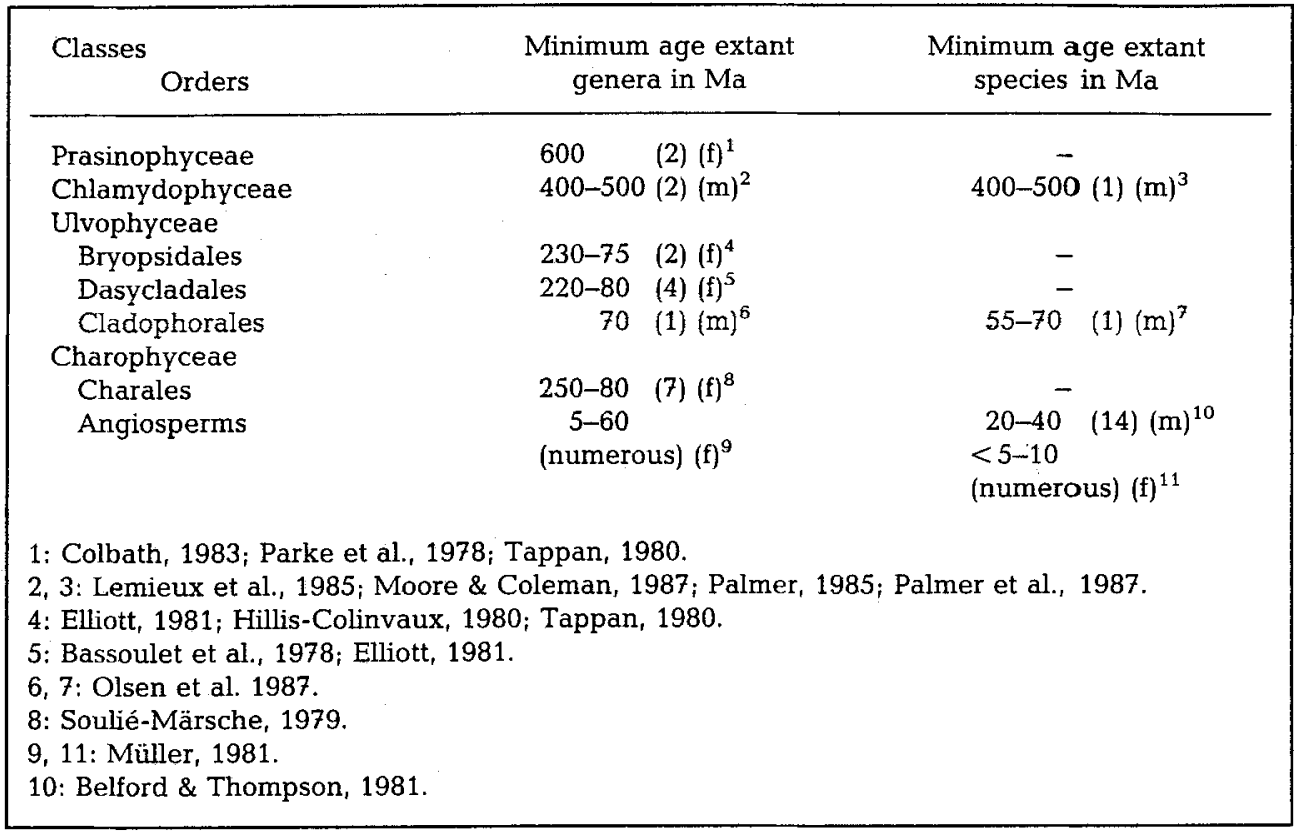

\section{CONCLUSIONS}

We do have some fossil evidence and some macromolecular evidence in support of the following hypotheses regarding the phylogeny of the chlorophytes.

(1) The free living green flagellates represent the oldest, most conservative lineages in the Chlorophyta, and they are ancestral to the other, non-flagellate Chlorophyta. This hypothesis has been formulated on the basis of mainly morphological, ultrastructural and life history evidence, and it is confirmed by a (limited) 5S rRNA phylogeny.

(2) The first implication of the hypothesis in paragraph 1 is that extant genera and species in the flagellate chlorophytes can be expected to be, on average, ancient and phenotypically conservative relative to genera and species in derived nonflagellate lineages. Fossil evidence indicates that the extant prasinophycean genera Pterosperma and Pachysphaera are probably at least $600 \mathrm{Ma}$ old. Comparison of chloroplast genomes suggest that the genus Chlamydomonas and the morphological species Pandorina morum are perhaps older than 400-500 Ma.

(3) The second implication of the hypothesis in paragraph 1 is that extant genera and species in the most derived Chlorophytes (the Angiosperms) can be expected to be, on average, young and morphologically changeable in comparison to the flagellate lineages. Fossil evidence indicates that many extant genera of flowering plants are at least 5-60 Ma old. DNA-DNA hybridization experiments with Atriplex species suggest species divergences between 20-40 Ma ago (Belford \& Thompson, 1981). Numerous flowering 
plant families (e.g. Brassicaceae, Primulaceae, Lamiaceae, Fabaceae) appeared as late as Miocene (10-5 Ma) (Mïller, 1981). Their genera and species are of course even younger.

(4) The third implication of the hypothesis in paragraph 1 is that extant genera and species in the chlorophytes of intermediate derivation (e.g. Ulvophyceae, Charophyceae) can be expected to have an intermediate age and morphological conservatism. Fossil evidence indicates that six extant genera in the Bryopsidales and Dasycladales are at least 230-80 Ma old, and that seven genera in the Charales are at least 250-80 Ma old. The genus Dictyosphaeria (Cladophorales) is estimated to be ca $70 \mathrm{Ma}$ old on the basis of DNA-DNA hybridization whereas the morphological species $D$. cavernosa is thought to be 55-70 Ma old (See Table 3 for a summary of items 1-4).

(5) The main phylogenetic lineages in the Chlorophyta are not represented by the progressively more derived organizational levels (flagellate level, coccoid level, sarcinoid level, filamentous level, siphonocladous level, siphonous level). This traditional hypothesis of chlorophytan evolution should now be abandoned. Dr. Kornmann's idea that divergent organizational levels have been realized within one chlorophytan group is correct.

\section{LITERATURE CITED}

Ayala, F. J., 1986. On the virtues and pitfalls of the molecular evolutionary clock. - Heredity 77, 226-235.

Bakker, M. E. \& Lokhorst, G. M., 1985. The ultrastructure of the flagellar apparatus of the zoospore of Chaetomorpha melagonium (Web. \& Mohr) Kützing (Chlorophyta). - Phycologia 24, 275-288.

Barlow, S. B. \& Cattolico, R. A., 1981. Mitosis and cytokinesis in the Prasinophyceae. I. Mantoniella squamata (Manton \& Parke) Desikachary. - Am. J. Bot. 68, 606-615.

Bassoulet, J. P., Bernier, P., Conrad, M. A., Deloffre, R. \& Jaffrezo, M., 1978. Les algues dasycladales du Jurassique et du Crétacée. - Geobios. Mém. Spécial 2, 1-330.

Belford, H. S. \& Thompson, W. F., 1981. Single copy DNA homologies in Atriplex. II. Hybrid thermal stabilities and molecular phylogeny. - Heredity 46, 109-122.

Blackman, F., 1900. The primitive algae and the Flagellata. - Ann. Bot. 14, 647-688.

Boalch, G. T. \& Parke, M., 1971. The prasinophycean genera (Chlorophyta) possibly related to fossil genera, in particular the genus Tasmanites. In: Proceedings of the 2nd Plankton Conference. Roma 1970. Ed. by A. Farinacci. 99-105.

Bold, H. C. \& Wynne, M. J., 1985. Introduction to the algae. Structure and reproduction. Prentice Hall, Englewood Cliffs, N. J., 720 pp.

Bold, H. C., Alexopoulos, C. J. \& Delevoryas, T., 1987. Morphology of plants and fungi. Harper \& Row, New York, 912 pp.

Brown, D. R., Massalski, A. \& Patenande, R., 1976. Organization of the flagellar apparatus and associated cytoplasmic microtubules in the quadriflagellate alga, Polytomella agilis. - J. Cell Biol. 69, 106-125.

Buchheim, M. A. \& Hoffmann, L. R., 1986. Ultrastructure of male gametes of Sphaeroplea robusta (Chlorophyceae). - J. Phycol. 22, 176-185.

Burr, F. \& West, J. A., 1970. Light and electron microscope observations on the vegetative and reproductive structures of Bryopsis hypnoides, - Phycologia 9, 17-37.

Chapman, R. L. 1981. Ultrastructure of Cephaletros virescens (Chroolepidaceae; Chlorophyta). III. Zoospores. - Am. J. Bot. 68, 544-556.

Chapman, R. L., 1984. An assessment of the current state of our knowledge of the Trentepohliaceae. In: Systematics of the green algae. Ed. by D. E. G. Irvine \& D. M. John. Acad. Press, London, $233-250$.

Chapman, R. L. \& Good, B. H., 1978. Ultrastructure of plasmodesmata and cross-walls in Cephaleuros, Phycopeltis and Trentepohlia (Chroolepidaceae; Chlorophyta). - Br. phycol. J. 13, 241-246. 
Chapman, R. L. \& Henk, M. C., 1983. Ultrastructure of Cephaleuros virescens (Chroolepidaceae; Chlorophyta). IV. Absolute configuration analysis of the cruciate flagellar apparatus and multilayered structures in the pre- and post-release gametes. - Am. J. Bot. 70, 1340-1355.

Chapman, R. L. \& Henk, M. C., 1985. Observations on the habit, morphology and ultrastructure of Cephaleuros parasiticus (Chlorophyta) and a comparison with C. virescens. - J. Phycol. 21. 513-522.

Chapman, R. L. \& Henk, M. C., 1986. Phragmoplasts in cytokinesis of Cephaleuros parasiticus (Chlorophyta) vegetative cells. - J. Phycol. 22, 83-88.

Chappell, D. F. \&.Floyd, G. L., 1981. Cell division in the weakly filamentous Raphidonema sessile (= Raphidonemopsis sessilis) (Chlorophyta). - Trans. Am. microsc. Soc. 100, 74-82.

Chardard, R., 1987. L'infrastructure du plasmalemme de Dunaliella bioculata (algue verte). Mise en évidence d'un cell-coat; essai de localisation des charges négatives. - Crypt. Algol. 8, 173-190.

Colbath, G. K., 1983. Fossil prasinophycean phycomata (Chlorophyta) from the Silurian Bainbridge formation, Missouri, U.S.A. - Phycologia 22, 249-265.

Deason, T. R., 1984. A discussion of the classes Chlamydophyceae and Chlorophyceae and their subordinate taxa. - Pl. Syst. Evol. 146, 75-81.

Deason, T. R. \& Floyd, G. L., 1987. Comparative ultrastructure of three species of Chlorosarcina (Chlorosarcinaceae, Chlorophyta). - J. Phycol. 23, 187-195.

Eckhardt, R. \& Schnetter, R., 1984. Failure of karyogamy after gamete mating in Derbesia tenuissima. - Naturwissenschaften 71,640-641.

Eckhardt, R., Schnetter, R. \& Seibold, G., 1986. Nuclear behaviour during the life cycle of Derbesia (Chlorophyceae). - Br. phycol. J. 21, 287-295.

Elliott, G. F., 1981. The Tethyan dispersal of some chlorophyte algae subsequent to the Paleozoic. Palaeogeogr. Palaeoclimat. Palaeoecol. 32, 341-358.

Enomoto, S. \& Ohba, H., 1987. Culture studies on Caulerpa (Caulerpales, Chlorophyceae). I. Reproduction and development of $C$. racemosa var. laetevirens. - Jap. J. Phycol. 35, 167-177.

Ettl, H., 1976. Die Gattung Chlamydomonas Ehrenberg. - Nova Hedwigia (Beih.) 49, 1-1122.

Ettl, H., 1981. Die neue Klasse Chlamydophyceae, eine natürliche Gruppe der Grünalgen (Chlorophyta). - Pl. Syst. Evol. 137, 107-126.

Ettl, H., 1983. Chlorophyta I (Phytomonadina). In: Süßwassserflora von Mitteleuropa. Hrsg. von H. Ettl, J. Gerloff \& H. Heynig. Fischer, Stuttgart, 9, 1-807.

Ettl, H. \& Komárek, J., 1982. Was versteht man unter dem Begriff „coccale Grünalgen“? - Algol. Stud. 29, 345-374.

Ettl, H. \& Moestrup, Ø., 1980. Light and electron-microscopical studies on Hafniomonas gen. nov. (Chlorophyceae, Volvocales), a genus resembling Pyramimonas (Prasinophyceae). - Pl. Syst. Evol. 135, 177-210.

Eyden, B. P., 1975. Light and electron microscope study of Dunaliella primolecta Butcher (Volvocida). - J. Protozool. 22, 336-344.

Floyd, G. L. \& Hoops, H. J., 1980. Schizomeris leibleinil revisited; ultrastructure of the flagellar apparatus, - J. Phycol. 16 (Suppl.), 11.

Floyd, G. L., Hoops, H. J. \& Swanson, J. A., 1980. Fine structure of the zoospore of Ulothrix belkae with emphasis on the flagellar apparatus. - Protoplasma 104, 17-31.

Floyd, G. L. \& O'Kelly, C. J., 1984. Motile cell ultrastructure and the circumscription of the orders Ulotrichales and ulvales (Ulvophyceae, Chlorophyta). - Am. J. Bot. 71, 111-120.

Floyd, G. L., O'Kelly, C. J. \& Chappell, D. F., 1985. Absolute configuration analysis of the flagellar apparatus in Cladophora and Chaetomorpha motile cells with an assessment of the phylogenetic position of the Cladophoraceae (Ulvophyceae, Chlorophyta.) - Am. J. Bot. 72, 615-625.

Floyd, G. L., Stewart, K. D. \& Mattox, K. R., 1972a. Comparative cytology of Ulothrix and Stigeoclonium. - J. Phycol. 8, 68-81.

Floyd, G. L., Stewart, K. D. \& Mattox, K. R., 1972b. Cellular organization, mitosis, and cytokinesis in the ulotrichalean alga, Klebsormidium. - J. Phycol. 8, 176-184.

Fott, B., 1971. Algenkunde. VEB Fischer, Jena, 581 pp.

Fritsch, F. E., 1948. The structure and reproduction of the algae. Cambridge Univ. Press, Cambridge, $1,1-791$.

Giddings, T. H., Brower, D. L. \& Staehelin, L. A., 1980. Visualization of particle complexes in the 
plasma membrane of Micrasterias denticulata associated with the formation of cellulose fibrils in primary and secondary cell walls. $-J$. Cell Biol. 84, 327-339.

Goodenough, U. W. \& Weiss, R. L., 1978. Interrelationships between microtubules, a striated fiber, and the gametic mating structure of Chlamydomonas reinhardtii. - J. Cell Biol. 76, 430-438.

Gori, P., 1979. Ultrastructure of the spermatozoid in Halimeda tuna (Chlorophyceae). - Gam. Res. 2, 345-355.

Graham, L. E., 1984. An ultrastructural re-examination of putative multilayered structures in Trentepohlia aurea. - Protoplasma 123, 1-7.

Graham, L. E. \& McBride, G. E., 19.75. The ultrastructure of multilayered structures associated with flagellar bases in motile cells of Trentepohlia aurea. - J. Phycol. 11, 86-96.

Graham, L. E. \& McBride, G. E., 1979. The occurrence and phylogenetic significance of a multilayered structure in Coleochaete spermatozoids. - Am. J. Bot. 66, 887-894.

Graham, L. E. \& Wedemeyer, G. J., 1984. Spermatogenesis in Coleochaete pulvinata (Charophyceae): sperm maturation. - J. Phycol. 20, 302-309.

Greuel, B. T. \& Floyd, G. L., 1985. Development of the flagellar apparatus and flagellar orientation in the colonial green alga Gonium pectorale (Volvocales). - J. Phycol. 21, 358-371.

Groover, R. D. \& Bold, H. C., 1969. The taxonomy and comparative physiology of the Chlorosarcinales and certain other edaphic algae. Phycological Studies VIII. - Univ. of Texas Publ. 6907, 1-165.

Hillis-Colinvaux, L., 1980. Ecology and taxonomy of Halimeda: primary producer of coral reefs. Adv. mar. Biol. 17, 1-327.

Hillis-Colinvaux, L., 1986. Distribution patterns of some Bryopsidales in the geologic past: their bearing on present distributions. - Botanica mar. 24, 271-277.

Hirayama, T. \& Hori, T., 1984. Flagellar apparatus of the quadriflagellated zoospore of Chaetomorpha spiralis Okamura (Cladophorales, Chlorophyta). - Botanica mar. 27, 335-344.

Hoek, C. van den, 1981. Chlorophyta: morphology and classification. In: The biology of seaweeds. Ed. by C. S. Lobban \& M. J. Wynne. Blackwell, Oxford, 86-132.

Hoek, C. van den, 1984a. The systematics of the Cladophorales. In: The systematics of the green algae. Ed. by D. E. G. Irvine \& D. M. John. Acad. Press, New York, 157-178.

Hoek, C. van den, 1984b. World-wide latitudinal and longitudinal seaweed distribution patterns and their possible causes, as illustrated by the distribution of Rhodophytan genera. - Helgoländer Meeresunters. 38, 227-257.

Hoek, C. van den \& Jahns, H. M., 1978. Algen. Thieme, Stuttgart, 481 pp.

Hoffmann, L. R., 1970. Observation on the fine structure of Oedogonium VI. The striated component of the compound flagellar "roots" of $O$. cardiacum. - Can. J. Bot. 48, 189-196.

Hoffmann, L. R., 1984. Male gametes of Atractomorpha echinata Hoffmann (Chlorophyceae). J. Phycol. 20, 573-584.

Hoops, H. J., 1984. Somatic cell flagellar apparatuses in two species of Volvox (Chlorophyceae). J. Phycol. 20, 20-27.

Hoops, H. J. \& Floyd, G. L., 1983. Ultrastructure and development of the flagellar apparatus and flagellar motion in the colonial green alga Astrephomene gubernaculifera. - J. Cell Sci. 63, $21-41$.

Hoops, H. J., Floyd, G. L. \& Swanson, J. A., 1982. Ultrastructure of the biflagellate motile cells of Ulvaria oxysperma (Kütz.). Bliding and phylogenetic relationships among Ulvophycean algae. Am. J. Bot. 69, 150-159.

Hori, H., Lim, B.-L. \& Osawa, S., 1985. Evolution of green plants as deduced from 5S rRNA sequences.-Proc. natn. Acad. Sci. USA 82, 820-823.

Hori, H. \& Osawa, S., 1987. Origin and evolution of organisms as deduced from 5 S ribosomal RNA sequences.-Mol. Biol. Evol. 4, 445-472.

Hori, T., 1977. Electron microscope observations on the flagellar apparatus of Bryopsis maxima (Chlorophyceae). - J. Phycol. 13, 238-243.

Hori, T., 1981. Ultrastructural studies on nuclear division during gametogenesis in Caulerpa (Chlorophyceae). - Jap. J. Phycol, 29, 163-170.

Hori, T. \& Enomoto, S., 1978a. Developmental cytology of Dictyosphaeria cavernosa. II. Nuclear division during zooid formation. - Botanica mar. 21, 477-481.

Hori, T. \& Enomoto, S., 1978b. Electron microscope observations on the nuclear division in Valonia ventricosa (Chlorophyceae, Siphonocladales). - Phycologia 17, 133-142. 
Hori, T., Inouye, I. Horiguchi, T. \& Boalch, G., 1985. Observations on the motile stage of Halosphaera minor Ostenfeld (Prasinophyceae) with special reference to the cell structure. - Botanica mar, 28, 529-537.

Hori, T. \& Kobara, T., 1982. Ultrastructure of the flagellar apparatus in the stephanokont zoospores of Pseudobryopsis hainanensis (Chlorophyceae). - Jap. J. Phycol, 30, 31-39.

Hori, T., Norris, R. E. \& Chihara, M., 1986. Studies on the ultrastructure and taxonomy of the genus Tetraselmis (Prasinophyceae). III. Subgenus Parviselmis. - Bot. Mag. Tokyo 99, 123-135.

Hotchkiss, A. T. \& Brown, R. M., 1987. The association of rosette and globule terminal complexes with cellulose microfibril assembly in Nitella translucens var. axillaris (Charophyceae). - J. Phycol. 23, 229-237.

Hudson, P. R. \& Waaland, J. R., 1974. Ultrastructure of mitosis and cytokinesis in the multinucleate green alga Acrosiphonia. - J. Cell Biol. 62, 274-294.

Huss, V. A. R., Dörr, R., Grossmann, U. \& Kessler, E., 1986. Deoxyribonucleic acid reassociation in the taxonomy of the genus Chlorella. I. Chlorella sorokiniana. - Arch. Mikrobiol. 145, 329-333.

Huss, V. A. R., Schwarzwälder, E. \& Kessler, E., 1987a. Deoxyribonucleic acid reassociation in the taxonomy of Chlorella. II. Chlorella saccharophila. - Arch. Mikrobiol. 147, 221-224.

Huss, V. A. R., Hehenberger, A. \& Kessler, E., 1987b. Deoxyribonucleic acid reassociation in the taxonomy of the genus Chlorella. III. Chlorella fusca and Chlorella kessleri. - Arch. Mikrobiol. 149, $1-3$.

Hyams, J. \& Chasey, D., 1974. Aspects of the flagellar apparatus and associated microtubules in a marine alga. - Exp. Cell Res. 84, 381-387.

Inouye, I., Hori, T. \& Chihara, M., 1983. Ultrastructure and taxonomy of Pyramimonas Iunata, a new marine species of the class Prasinophyceae. - Jap. J. Phycol. 31, 238-249.

Inouye, I., Hori, T. \& Chihara, M., 1985. Ultrastructural characters of Pyramimonas and their possible relevance on taxonomy. In: Origin and evolution of diversity in plants and plant communities. Ed. by H. Hara. Academia Scientific Book, Tokyo, 314-327.

Jónsson, S. \& Chesnoy, L., 1984. Aspectes ultrastructuraux de la fécondation chez l'Acrosiphonia spinescens (Kütz.) Kjellm. (Acrosiphoniales, Chlorophyta). - Bull. Soc. bot. Fr. 131, 247-263.

Joosten, A. M. T. \& Hoek, C. van den, 1986. World-wide relationships between red seaweed floras: a multivariate approach. - Botanica mar. 29, 195-214.

Katz, K. R. \& McLean, R. J., 1979. Rhizoplast and rootlet systems of the flagellar apparatus of Chlamydomonas moewusii. - J. Cell Sci. 39, 373-381.

Kessler, E., 1984. A general review on the contribution of chemotaxonomy to the systematics of green algae. In: Systematics of the green algae. Ed. by D.E.G. Irvine \& D. M. John. Acad. Press, London, 391-407.

Kloppstech, K., 1982. Acetabularia. In: The molecular biology of plant development. Ed. by H. Smith \& D. Grierson. Blackwell, Oxford, 136-158.

Komárek, J. \& Fott, B., 1983. Chlorophyceae (Grünalgen). Ordnung: Chlorococcales. In: Die Binnengewässer. Hrsg. von August Thienemann. Schweizerbart, Stuttgart, 16 (7,1),1-1044.

Koop, H. U., 1975. Über den Ort der Meiose bei Acetabularia mediterranea. - Protoplasma 85, 109-114.

Koop, H. U., 1979. The life cycle of Acetabularia (Dasycladales, Chlorophyceae): a compilation of evidence for meiosis in the primary nucleus. - Protoplasma 100, 353-366.

Kornmann, P., 1938. Zur Entwicklungsgeschichte von Derbesia und Halicystis. - Planta 28, 464-470.

Kornmann, P., 1963. Die Ulotrichalen neugeordnet auf der Grundlage entwicklungsgeschichtlicher Befunde. - Phycologia 3, 60-68.

Kornmann, P., 1973. Codiolophyceae, a new class of Chlorophyta. - Helgoländer wiss. Meeresunters. $25,1-13$.

Kornmann, P. \& Sahling, P.-H., 1983. Meeresalgen von Helgoland: Ergänzung. - Helgoländer Meeresunters. 36, 1-65.

Lembi, C. A., 1975. A rhizoplast in Carteria radiosa (Chlorophyceae). - J. Phycol. 11, 219-221.

Lembi, C. A., 1980. Unicellular chlorophytes. In: Phytoflagellates. Ed by E. R. Cox. Elsevier, Amsterdam, 5-59.

Lemieux, B., Turmel, M. \& Lemieux, C., 1985. Chloroplast DNA variation in Chlamydomonas and its potential application to the systematics of this genus. - BioSystems 8, 293-298. 
Liddle, L., Berger, S. \& Schweizer, M. S., 1976. Ultrastructure during development of the nucleus of Batophora oerstedii (Chlorophyta, Dasycladaceae). - J. Phycol. 12, 261-272.

Lokhorst, G. M., 1984. Current ideas on classification of the Ulotrichales Borzi. In: Systematics of the green algae. Ed. by D. E. G. Irvine \& D. M. John. Acad. Press, London, 179-206.

Lokhorst, G. M., 1985. The concept of the genus Ulothrix (Chlorophyta) strengthened by comparative cytology, - BioSystems 18, 357-368.

Lokhorst, G. M., 1987. The ultrastructure of mitosis and cytokinesis in Chlorokybus atmophyticus: cleavage microtubules in a charophycean alga. - 14th Int. Bot. Congr. Berlin, Abstr. 261.

Lokhorst, G. M. \& Star, W., 1983. Fine structure of mitosis and cytokinesis in Urospora (Acrosiphoniales, Chlorophyta). - Protoplasma 117, 142-153.

Lokhorst, G. M. \& Star, W., 1985. Ultrastructure of mitosis and cytokinesis in Klebsormidium mucosum nov. comb., formerly Ulothrix verrucosa (Chlorophyta). - J. Phycol. 21, 466-476.

Lokhorst, G. M. \& Vroman, M., 1972. Taxonomic study on three freshwater Ulothrix species. - Acta bot. neerl. $21,449-480$.

Løvlie, A. \& Brăten, T., 1968. On the division of cytoplasm and chloroplast in the multicellular green alga UIva mutabilis Føyn. - Exp. Cell Res. 51, 211-220.

Løvlie, A. \& Brăten, T., 1970. On mitosis in the multicellular alga Ulva mutabilis Føyn. - J. Cell Sci. 6, 109-129.

Manton, I. \& Parke, M., 1960. Further observations on small green flagellates with special reference to possible relatives of Chromulina pusilla Butcher. - J. mar. biol. Ass. U.K. 39, 275-298.

Markowitz, M., 1978. Fine structure of the zoospore of Oedocladium carolinianum (Chlorophyta) with special reference to the flagellar apparatus. - J. Phycol. 14, 289-302.

Marchant, H. J. \& Pickett-Heaps, J. D., 1973. Mitosis and cytokinesis in Coleochaete scutata. J. Phycol. 9, 461-471.

Marchant, H. J., Pickett-Heaps, J. D. \& Jacobs, K., 1973. An ultrastructural study of zoosporogenesis and the mature zoospore of Klebsormidium flaccidum. - Cytobios 8, 95-107.

Mattox, K. R. \& Stewart, K. D., 1977. Cell division in the scaly green flagellate Heteromastix rugulata and its bearing on the origin of the Chlorophyceae. - Am. J. Bot. 64, 931-945.

Mattox, K. R. \& Stewart, K. D., 1984. Classification of the green algae: a concept based on comparative cytology. In: Systematics of the green algae. Ed, by D. E. G. Irvine \& D. M. John. Acad. Press, London, 29-72.

Mattox, K. R., Stewart, K. D. \& Floyd, G. L., 1974. The cytology and classification of Schizomeris leibleinii. I. The vegetative thallus. - Phycologia 13,63-69.

McArthur, D. M. \& Moss, B. L., 1978. Ultrastructural studies of vegetative cells, mitosis and cell division in Enteromorpha intestinalis (L.) Link. - Br. phycol. J. 13, 255-267.

McBride, G. E., 1967. Cytokinesis in the green alga Fritschiella tuberosa. - Nature, Lond. 216, 939.

McBride, G. E., 1970. Cytokinesis and ultrastructure in Fritschiella tuberosa Iyengar. - Arch. Protistenk, 112, 365-375.

McDonald, K. L. \& Pickett-Heaps, J. D. 1976. Ultrastructure and differentiation in Cladophora glomerata. I. Cell division. - Am. J. Bot. 63, 592-601.

Meinesz, A., 1969. Sur la reproduction sexuée de l'Udotea petiolata (Turr.) Boerg. - C. r. hebd. Séanc, Acad. Sci, Paris 269, 1063-1065.

Meinesz, A., 1972a. Sur le cycle de l'Halimeda tuna (Ellis et Solander) Lamouroux (Udotéacée, Caulerpale). - C. r. hebd. Séanc. Acad. Sci., Paris 275, 1363-1365.

Meinesz, A., 1972b. Sur le cycle d'Udotea petiolata (Turr.) Boerg. (Caulerpale, Udotéacée). - C. r. hebd. Séanc. Acad. Sci., Paris 275, 1975-1977.

Meinesz, A., 1980. Connaissances actuelles et contribution à l'étude de la reproduction et du cycle des Udotéacées (Caulerpales, Chlorophytes). - Phycologia 19, 110-138.

Melkonian, M., 1977. The flagellar root system of zoospores of the green alga Chlorosarcinopsis (Chlorosarcinales) as compared with Chlamydomonas (Volvocales). - Pl. Syst. Evol, 128, 79-88.

Melkonian, M., 1978. Structure and significance of cruciate flagellar root systems in green algae: comparative investigations in species of Chlorosarcinopsis (Chlorosarcinales). - Pl. Syst. Evol. $130,265-292$.

Melkonian, M., 1979. Structure and significance of cruciate flagellar root systems in green algae: zoospores of Ulva lactuca (Ulvales, Chlorophyceae). - Helgoländer wiss. Meeresunters. 32, 425-435. 
Melkonian, M., 1980. Flagellar roots, mating structure and gamete fusion in the green alga Ulva lactuca (Ulvales). - J. Cell Sci. 46, 149-169.

Melkonian, M., 1981a. The flagellar apparatus of the scaly green flagellate Pyramimonas aborata: absolute configuration. - Protoplasma 108, 341-355.

Melkonian, M., 1981b. Structure and significance of cruciate flagellar root systems in green algae: female gametes of Bryopsis lyngbyei (Bryopsidales). - Helgoländer wiss. Meeresunters. 34, 355-369.

Melkonian, M., 1982. Structural and evolutionary aspects of the flagellar apparatus in green algae and land plants. - Taxon 31, 255-265.

Melkonian, M., 1983. Functional and phylogenetic aspects of the basal apparatus in algal cells. J. submicrosc. Cytol. 15, 121-125.

Melkonian, M., 1984. Flagellar apparatus ultrastructure in relation to green algal classification. In: Systematics of the green algae. Ed. by D. E. G. Irvine \& D. M. John. Acad. Press, London, 73-120.

Melkonian, M. \& Berns, B., 1983. Zoospore ultrastructure in the green alga Friedmannia israelensis: an absolute configuration analysis. - Protoplasma 114, 67-84.

Melkonian, M. \& Preisig, H. R., 1984. An ultrastructural comparison between Spermatozopsis and Dunaliella (Chlorophyceae). - Pl. Syst. Evol. 146, 31-46.

Melkonian, M., Reize, I. B. \& Preisig, H. R., 1987. Maturation of a flagellum/basál body requires more than one cell cycle in algal flagellates: studies on Nephroselmis olivacea (Prasinophyceae). In: Algal development. Ed. by W. Wiesner, D. G. Robinson \& R. C. Starr. Springer, Berlin, 102-113.

Meyen, S. V., 1987. Fundamentals of palaeobotany. Chapman \& Hall, London, $432 \mathrm{pp}$.

Miyaji, K. \& Hori, T., 1984. The ultrastructure of Spongomorpha duriuscula (Acrosiphoniales, Chlorophyta), with special reference to the flagellar apparatus. - Jap. J. Phycol. 32, 307-318.

Mizuta, S., 1987. Structure and generation of cell walls in cellulosic algae II. Microfibril formation and regulation of orientation. - Jap. J. Phycol. 35, 130-143.

Moestrup, $\varnothing ., 1970$. The fine structure of the mature spermatozoids of Chara corallina, with special reference to microtubules and scales. - Planta 93, 295-308.

Moestrup, Ø., 1974. Ultrastructure of the scale-covered zoospore of the green alga Chaetosphaeridium, a possible ancestor of the higher plants and bryophytes. - Biol. J. Linn. Soc. 6 111-125.

Moestrup, Ø., 1978. On the phylogenetic validity of the flagellar apparatus in green algae and other chlorophyll $\mathrm{a}$ and $\mathrm{b}$ containing plants. - BioSystems 10,117-144.

Moestrup, Ø., 1982. Flagellar structure in algae: a review, with new observations particularly on the Chrysophyceae, Phaeophyceae (Fucophyceae), Euglenophyceae, and Reckertia. - Phycologia $21,427-528$.

Moestrup, $\varnothing ., 1987$. The importance of flagellar apparatus ultrastructure in algal systematics and phylogeny. - 14th Int. Bot. Congr. Berlin, Abstr. 259.

Moestrup, $\varnothing$. \& Ettl, H., 1979. A light and electron microscopical study of Nephroselmis olivacea (Prasinophyceae). - Op. bot. 49, 1-39.

Moestrup, Ø. \& Walne, P. L. 1979. Studies on scale morphogenesis in the Golgi-apparatus of Pyramimonas tetrarhynchus (Prasinophyceae). - J. Cell Sci. 36, 437-459.

Moore, L. J. \& Coleman, A. W., 1987. Do the chloroplast DNAs of Pandorina morum (Volvocales, Chlorophyta) evolve at the same rate as cp DNAs of flowering plant species? - 14th Int. Bot. Congr. Berlin, Abstr. 178.

Müller, J., 1981. Fossil pollen records of extant angiosperms. - Bot. Rev. 47, 1-142.

Nei, M., 1987. Molecular evolutionary genetics. Columbia Univ. Press, New York, 512 pp.

Neumann, K., 1969a. Protonema mit Riesenkern bei der siphonalen Grünalge Bryopsis hypnoides und weitere cytologische Befunde. - Helgoländer wiss. Meeresunters. 19, 45-57.

Neumann, K., 1969b. Beitrag zur Cytologie und Entwicklung der siphonalen Grünalge Derbesia marina. - Helgoländer wiss. Meeresunters. 19, 355-375.

Norris, R. E., 1980. Prasinophytes. In: Phytoflagellates. Ed. by E. R. Cox. Elsevier, Amsterdam, 85-145.

Norris, R. E., 1982. Prasinophyceae. In: Synopsis and classification of living organisms. Ed. by S. P. Parker. McGraw-Hill, New York, 1, 162-164.

Norris, R. E. \& Pienaar, R. N., 1978. Comparative fine-structural studies on five marine species of Pyramimonas (Chlorophyta, Prasinophyceae). - Phycologia 17, 41-51. 
O'Kelly, C. J. \& Floyd, G. J., 1983. The flagellar apparatus of Entocladia viridis motile cells, and the taxonomic position of the resurrected family Ulvellaceae (Ulvales, Chlorophyta). - J. Phycol. 19, 153-164.

O'Kelly, C. J. \& Floyd, G. L., 1984. Flagellar apparatus absolute orientations and the phylogeny of the green algae. - BioSystems 16, 227-251.

O'Kelly, C. J., Floyd, G. L. \& Dube, M. A., 1984. The fine structure of motile cells in the genera Ulvaria and Monostroma, with special reference to the taxonomic position of Monostroma oxyspermum (Ulvophyceae, Chlorophyta). - Pl. Syst. Evol. 144, 179-199.

Olsen, J. L., Stam, W. T., Bot., P. V. M. \& Hoek, C. van den, 1987. scDNA-DNA hybridization studies in Pacific and Caribbean isolates of Dictyosphaeria cavernosa (Chlorophyta) indicate a long divergence. - Helgoländer Meeresunters. 41, 377-383.

Olsen-Stojkovich, J., 1986. Phylogenetic studies of genera in the Siphonocladales-Cladophorales complex (Chlorophyta). Diss. Univ. of California, Berkeley, $183 \mathrm{pp}$.

Olsen-Stojkovich, J., West, J. A. \& Lowenstein, J. M., 1986. Phylogenetics and biogeography in the Cladophorales complex (Chlorophyta): Some insights from immunological distance data. Botanica mar. 29, 239-249.

Palmer, J. D., 1985. Comparative organization of chloroplast genomes. - A. Rev. Genet. 19. 325-354.

Palmer, J. D., Herbon, L. A., Milligan, B. G., Baldauf, S. L., Hampton, J. N. \& Calie, J. P., 1987. Evolution of chloroplast chromosomes in land plants. - 14th Int. Bot. Congr. Berlin, Abstr. 155.

Parke, M., Boalch, G. T., Jowett, R. \& Harbour, D. S., 1978. The genus Pterosperma (Prasinophyceae): species with a single equatorial ala. - J. mar. biol. Ass. U. K. 58, 239-276.

Pascher, A., 1914. Über Flagellaten und Algen. - Ber. dt. bot. Ges. 32, 136-160.

Pearson, B. R. \& Norris, R. E., 1975. Fine structure of cell division in Pyramimonas parkeae. J. Phycol. 11, 113-124.

Pennick, N. C., 1984. Comparative ultrastructure and occurrence of scales in Pyramimonas (Chlorophyta, Prasinophyceae). - Arch. Protistenk. 128, 3-11.

Pickett-Heaps, J. D., 1972. Cell division in Klebsormidium subtilissimum (formerly Ulothrix subtilissima) and its possible phylogenetic significance. - Cytobios 6, 167-183.

Pickett-Heaps, J. D., 1974. Cell division in Stichococcus. - Br. phycol. J. 9, 63-73.

Pickett-Heaps, J. D., 1975. Green algae. Structure, reproduction and evolution in selected genera. Sinauer, Sunderland, Mass., $606 \mathrm{pp}$.

Pickett-Heaps, J. D., 1976. Cell division in Raphidonema longiseta. - Arch. Protistenk. 118, $209-214$.

Price, I. R., 1972. Zygote development in Caulerpa (Chlorophyta, Caulerpales). - Phycologia 11, $217-218$.

Pienaar, R. N. \& Aken, M. E., 1985. The ultrastructure of Pyramimonas pseudoparkeae sp. nov. (Prasinophyceae) from South Africa. - J. Phycol. 21, 428-447.

Rietema, H., 1969. A new type of life history in Bryopsis. - Acta bot. neerl. 18, 615-619.

Rietema, H., 1970. Life histories of Bryopsis plumosa from European coasts. - Acta bot. neerl. 19, 859-866.

Rietema, H., 1971. Life history studies in the genus Bryopsis (Chlorophyceae). IV. Life histories in Bryopsis hypnoides Lamx. from different points along the European coasts. - Acta bot. neerl. 20, 291-298.

Rietma, H., 1972. A morphological, developmental, and caryological study on the life-history of Bryopsis halymeniae (Chlorophyceae). - Neth. J. Sea. Res. 5, 445-457.

Rietema, H., 1975. Comparative investigations on the life histories and reproduction of some species in the siphoneous green algal genera Bryopsis and Derbesia. Thesis, Groningen, $130 \mathrm{pp}$.

Ringo, D. L., 1967. Flagellar motion and fine structure of the flagellar apparatus in Chlamydomonas. - J. Cell Biol. 33, 543-571.

Roberts, K. R., 1984. The flagellar apparatus in Batophora and Trentepohlia and its phylogenetic significance. In: Systematics of the green algae. Ed. by D. E. G. Irvine \& D. M. John. Acad. Press, London, 331-341.

Roberts, K. R., Sluiman, H. J., Stewart, K. D. \& Mattox, K. R., 1980. Comparative cytology and taxonomy of the Ulvaphyceae. II. Ulvalean characteristics of the stephanokont flagellar apparatus of Derbesia tenuissima. - Protoplasma 104, 223-238.

Roberts, K. R., Sluiman, H. J., Stewart, K. D. \& Mattox, K. R., 1981. Comparative cytology and 
taxonomy of the Ulvaphyceae. III. The flagellar apparatus of the anisogametes of Derbesia tenuissima (Chlorophyta). - J. Phycol. 17, 330-340.

Roberts, K. R., Stewart, K. D. \& Mattox, K. R., 1982. Structure of the anisogametes of the green siphon Pseudobryopsis sp. (Chlorophyta). - J. Phycol. 18, 498-508.

Rogers, C. E., Mattox, K. R. \& Stewart, K. D., 1980. The zoospore of Chlorokybus atmophyticus, a charophyte with sarcinoid growth habit. - Am. J. Bot. 67, 774-783.

Schlösser, U. G., 1987. Action of cell wall autolysins in asexual reproduction of filamentous green algae: evidence and species specificity. In: Algal development. Ed. by W. Wiesner, D. G. Robinson \& R. C. Starr. Springer, Berlin, 75-82.

Schnetter, R., Eckhardt, R. \& Seibold, G., 1985. Die Kernphase von Sporophytenfäden der Grünalge Derbesia tenuissima (de Not.) Cm. - Beitr. Biol. Pfl. 60, 293-302.

Scott, J. L. \& Bullock, K. W., 1976. Ultrastructure of cell division in Cladophora: Pregametangial cell division in the haploid generation of Cladophora flexuosa. - Can. J. Bot. 54, 1546-1566.

Shihira-Ishikawa, I. \& Kuoiwa, T., 1984, Morphological transition of the nucleus during the whole life cycle of Acetabularia calyculus Quoy et Gaymard. - Jap. J. Phycol. 32, 147-157.

Sluiman, H. J., 1983. The flagellar apparatus of the zoospore of the filamentous green alga Coleochaete pulvinata: absolute configuration and phylogenetic significance. - Protoplasma 115, $160-175$.

Sluiman, H. J., 1984. A pathway of plasma membrane biogenesis bypassing the Golgi apparatus during cell division in the green alga Cylindrocapsa geminella. - J. Cell Sci. 72, 89-100.

Sluiman, H. J., 1985a. Mitosis and cell division in Cylindrocapsa geminella (Chlorophyceae). J. Phycol. 21, 523-532.

Sluiman, H. J., 1985b. Comparative studies on the ultrastructure, phylogeny and classification of green algae. Thesis, Vrije Univ., Amsterdam, $155 \mathrm{pp}$.

Sluiman, H. J., Mattox, K. R. \& Stewart, K. D., 1980a. Moderne opvattingen over de fylogenie van groenwieren en landplanten. - Vakbl. Biol. 60, 204-212.

Sluiman, H. J., Roberts, K. R., Stewart, K. D. \& Mattox, K. R., 1980b. Comparative cytology and taxonomy of Ulvaphyceae. I. The zoospore of Ulothrix zonata (Chlorophyta). - J. Phycol. 16, $537-545$.

Sluiman, H. J., Roberts, K. R., Stewart, K. D., Mattox, K. R. \& Lokhorst, G. L., 1982. The flagellar apparatus of the zoospore of Urospora penicilliformis (Chlorophyta). - J. Phycol. 18, 1-12.

Sluiman, H. J., Roberts, K. R., Stewart, K. D. \& Mattox, K. R., 1983. Comparative cytology and taxonomy of the Ulvophyceae. IV. Mitosis and cytokinesis in Ulothrix (Chlorophyta). - Acta bot. neerl. $32,257-269$.

Soulié-Märsche, I., 1979. Origine et évolution des genres actuels des Characeae. - Bull. cent. Rech. Explor. Prod. Elf-Aquitaine 3, 821-831.

Spring, H., Grierson, D., Hemleben, H., Stöhr, M., Krohne, G., Stadler, J. \& Franke, W. W., 1978. DNA contents and numbers of nucleoli and pre-rRNA genes in nuclei and gametes and vegetative cells of Acetabularia mediterranea. - Expl. Cell Res. 114, 203-215.

Stam, W. T., Bot, P. V. M., Boele-Bos, S. A., Rooy, J. van \& Hoek, C. van den, 1988. Single copy DNADNA hybridizations among five species of Laminaria (Phaeophyceae): phylogenetic and biogeographic implications. - Helgoländer Meeresuntes. 42, 251-267.

Stewart, K. D. \& Mattox, K. R., 1975. Some aspects of mitosis in primitive green algae: phylogeny and function. - BioSystems 7, 310-315.

Stewart, K. D. \& Mattox, K. R., 1978. Structural evolution in the flagellated cells of green algae and land plants. - BioSystems 10, 145-152.

Stewart, K. D., Mattox, K. R. \& Chandler, D. C., 19+4. Mitosis and cytokinesis in Platymonas subcordiformis, a scaly green monad. - J. Phycol. 10, 65-79.

Stuessy, C. L., Floyd, G. L. \& O'Kelly, C. J., 1983. Fine structure of zoospores of an Enteromorpha species (Ulvales, Chlorophyta) collected from freshwater. - Br. phycol. J. 18, 249-257.

Tanner, C., 1981. Chlorophyta: life histories. In: The biology of seaweeds. Ed. by C. S. Lobban \& M. J. Wynne. Blackwell, Oxford, 218-247.

Tappan, H., 1980. The paleobiology of plant protists. Freeman, San Francisco, 1028 pp.

Thomas, B. A. \& Spicer, R. A., 1986. The evolution and paleobiology of land plants. Croom Helm, Beckenham, Kent, 309 pp. 
Thorpe, J. P., 1982. The molecular clock hypothesis: biochemical evolution, genetic differentiation and systematics. - A. Rev. Ecol. Syst. 13, 136-168.

Triemer, R. E. \& Brown, R. M., 1974. Cell division in Chlamydomonas moewusii. - J. Phycol. 10, 419-443.

Woods, J. K. \& Triemer, R. E., 1981. Mitosis in the octoflagellate prasinophyte, Pyramimonas amylifera (Chlorophyta), - J. Phycol. 17, 81-90. 